JOINT TRANSPORTATION RESEARCH PROGRAM

FHWA/IN/JTRP-2009/23

Final Report

CREATION OF A COMMITTED JOHNSONGRASS AREA AND IMPLEMENTATION STUDY

D. James Morre

July 2009 
Final Report

FHWA/IN/JTRP-2009/23

\title{
Creation of a Committed Johnsongrass Research Test Area and Implementation Study
}

\author{
by \\ D. James Morre \\ Professor \\ Department of Medicinal Chemical and Molecular Pharmacology \\ Purdue University
}

Joint Transportation Research Program

Project No. C-36-48S

File No. 9-5-19

SPR-2981

Prepared in Cooperation with the

Indiana Department of Transportation and the

U.S. Department of Transportation

Federal Highway Administration

The contents of this report reflect the views of the author who is responsible for the facts and the accuracy of the data presented herein. The contents do not necessarily reflect the official views or policies of the Indiana Department of Transportation or the Fedeeral Highway Administration at the time of publication. This report does not constitute a standard, specification, or regulation.

Purdue University

West Lafayette, Indiana 47907

July 2009 


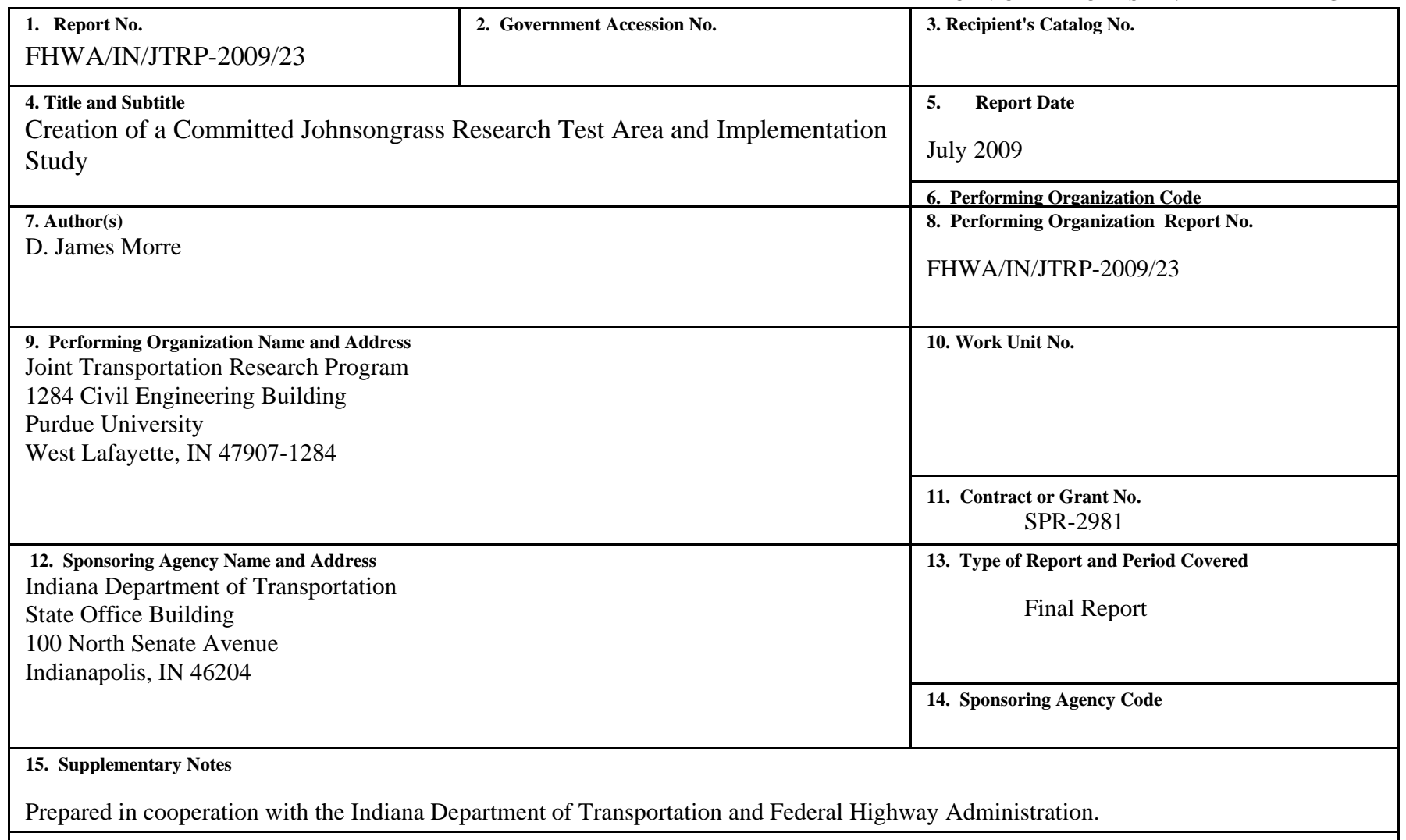

\section{Abstract}

This project was to develop a committed roadside Johnsongrass research area with controlled mowing and date of spraying adjacent to US 63 from I 74 south to JCT US 36 and to continue studies of a cold-adapted Johnsongrass ecotype identified in the Northern-most tier counties in Indiana in an area adjacent to IN 23 between South Bend and New Liberty, IN. The cold-adapted Johnsongrass provides a further threat of encroachment of roadside-established Johnsongrass onto adjacent cropland of considerable potential economic consequence.

Completed was a 3-year study with Roundup alone and in combination with Outrider either as a tank mix or sequentially with Roundup followed after several weeks by Outrider or Outrider followed after several weeks by Roundup comparing different rates, dates of application and stages of development. Roundup alone or in sequence several weeks following Outrider was without effect on Johnsongrass regrowth. A small benefit from $0.4 \mathrm{lb} / \mathrm{A}$ Roundup 3 to 6 weeks post Outrider was insufficient to justify the additional cost and offered no benefit over post Outrider mowing at the same stage. Correlations were with stage of growth with Johnsongrass 24 to 30 " tall, 33-36" tall and 40-42" tall without seed heads, seed heads forming in the boot, early anthesis (flowering), late flowering or with seed heads formed and 50-60" tall and spray date.

Fall 2006 marked initiation of the final implementation of the project. Outrider alone at a rate of 0.5 oz/100 gal plus a detergent at $0.12 \%$ of the total spray mixture spot sprayed to the point of runoff is to be recommended. Best results are expected with regrowth following mowing although about $>90 \%$ control can be expected from midseason to late spraying of mature Johnsongrass. Evaluated in 2007 and 2008 was the optimum regrowth stage to treat and the response to mowing following spraying. Johnsongrass can be mowed very soon after spraying (next day or late same day) without loss of treatment effectiveness.

In laboratory studies, a candidate Outrider binding protein was identified and cloned.

\author{
17. Key Words \\ Johnsongrass, Chemical Control, Outrider, Growth Stage, Cold- \\ Adapted Ecotype.
}

\section{Distribution Statement}

No restrictions. This document is available to the public through the National Technical Information Service, Springfield, VA 22161

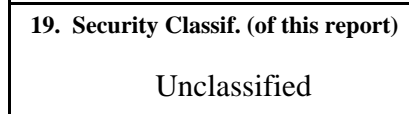

Form DOT F 1700.7 (8-69) 


\section{TABLE OF CONTENTS}

Introduction (Problem Statement and Objectives) $\ldots \ldots \ldots \ldots \ldots \ldots \ldots \ldots \ldots$

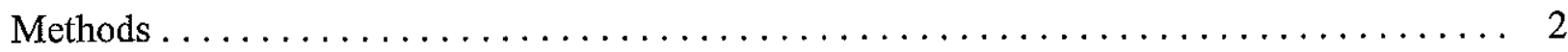

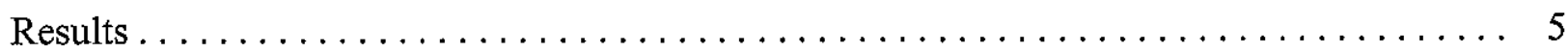

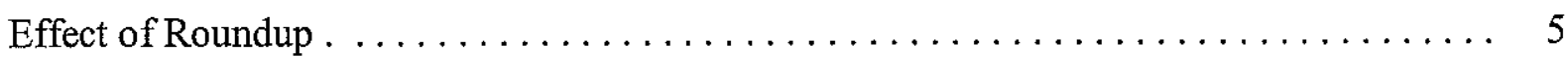

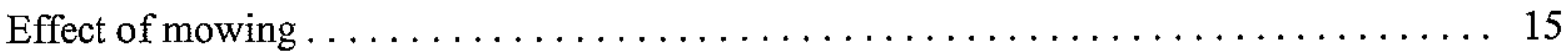

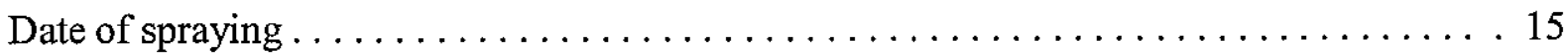

Developmental stage at time of spraying $\ldots \ldots \ldots \ldots \ldots \ldots \ldots \ldots \ldots \ldots \ldots$

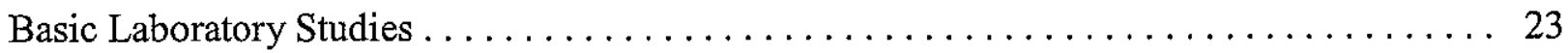

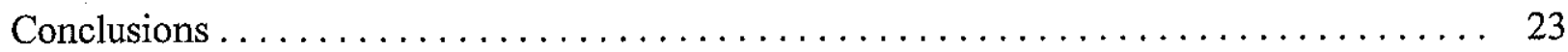

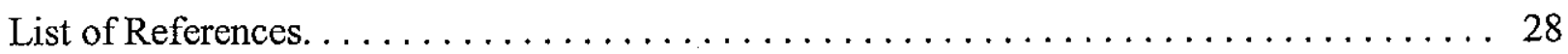

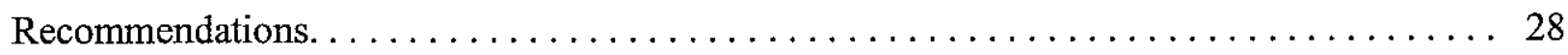

Implementation Suggestions $\ldots \ldots \ldots \ldots \ldots \ldots \ldots \ldots \ldots \ldots \ldots \ldots \ldots \ldots \ldots$ 


\begin{abstract}
This project was to develop a committed roadside Johnsongrass research area with controlled mowing and date of spraying adjacent to US 63 from I 74 south to JCT US 36 and to continue studies of a cold-adapted Johnsongrass ecotype identified in the Northern-most tier counties in Indiana in an area adjacent to IN 23 between South Bend and New Liberty, IN. The cold-adapted Johnsongrass provides a further threat of encroachment of roadside-established Johnsongrass onto adjacent cropland of considerable potential economic consequence.

Completed was a 3-year study with Roundup alone and in combination with Outrider either as a tank mix or sequentially with Roundup followed after several weeks by Outrider or Outrider followed after several weeks by Roundup comparing different rates, dates of application and stages of development was completed. Roundup alone or in sequence several weeks following Outrider was without effect on Johnsongrass regrowth. A small benefit from $0.4 \mathrm{lb} / \mathrm{A}$ Roundup 3 to 6 weeks post Outrider was insufficient to justify the additional cost and offered no benefit over post Outrider mowing at the same stage. Correlations were with stage of growth with Johnsongrass 24 to 30 " tall, 33-36: tall and 40-42" tall without seed heads, seed heads forming in the boot, early anthesis (flowering), late flowering or with seed heads formed and 50-60" tall and spray date.

Fall 2006 marked initiation of the final implementation phase of the project. Outrider alone at a rate of $0.5 \mathrm{oz} / 100$ gal. plus a detergent at $0.12 \%$ of the total spray mixture spot sprayed to the point of runoff is to be recommended. Best results are expected with regrowth following mowing although about $>90 \%$ control can be expected from midseason to late spraying of mature Johnsongrass. Evaluated in 2007 and 2008 was the optimum regrowth stage to treat and the response to mowing following spraying. Johnsongrass can be mowed very soon after spraying (next day or late same day) without loss of treatment effectiveness.
\end{abstract}

In laboratory studies, a candidate Outrider binding protein was identified and cloned. 


\section{TABLE OF FIGURES}

Figure 1. Uniform test area on US 63 north of Vermillion River. Johnsongrass was 48 inches tall. Photographed August 30, 2005 prior to spraying. . . . . . . . . 4

Figure 2. Uniform test area on US 63 north of Vermillion River. Photographed on September 29, 2006 one year after spraying with a broadcast application of $1 \mathrm{oz} / \mathrm{A}$ of Outrider plus detergent at $0.12 \%$ total spray mixture . . . . . . . . 4

Figure 3. Unmowed mature Johnsongrass in a fence row on a side road adjacent to the Uniform Test Area on US $63 \mathrm{~N}$ just south of the Vermillion River. The Johnsongrass in the foreground was mowed as part of an experimental mowing trial. . . . . . . . . . . . . . . . . . 18

Figure 4. Unmowed mature Johnsongrass behind a guardrail on a bridge approach on I 70 north of Wabash River bridge. Photographed August 23, 2005 . . . . . 18

Figure 5. Johnsongrass in Northern Indiana Test Area adjacent to IN 123 between South Bend and New Liberty. The area in the foreground was sprayed with $0.2 \mathrm{lb} / \mathrm{A}$ Roundup on August 11, 2004. The area was photographed on September 16, 2004.

Figure 6. Unmowed mature Johnsongrass in a fence row on Old Romney Road near Lafayette, Indiana photographed on August 3, 2005 prior to spraying

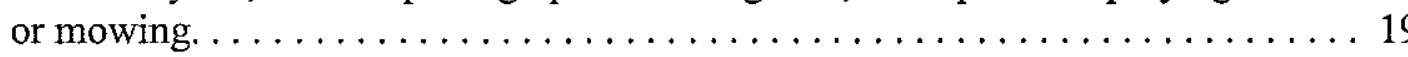

Figure 7. Area sprayed to point of runoff with $0.5 \mathrm{oz} / 100$ gal Outrider + detergent at $0.12 \%$ of the total spray mixture on August 3,2005 with evaluation on June 12, 2007. The Johnsongrass was unmowed. Control was $100 \%$. . . . . 20

Figure 8. As in Figure 7 except that the Johnsongrass was mowed 2 weeks after spraying. Control was $>98 \%$. Photographed June $12,2007 \ldots \ldots \ldots \ldots \ldots$

Figure 9. Correlation between Johnsongrass height at the time of application and percent control for a broadcast application of $1 \mathrm{oz} / \mathrm{A}$ Outrider plus detergent $(0.12 \%$ of total spray mixture) (40 gpa) in 2005 comparing different dates of application as indicated. . . . . . . . . . . . . . . . .

Figure 10. Inhibition of activity of the candidate Outrider receptor protein expressed in bacteria by different concentrations of Outrider . . . . . . . . . . 24

Figure 11. Area adjacent to US 41 north of Terre Haute, Indiana containing both mowed and unmowed Johnsongrass photographed on September 10, 2007 at time of spraying with $0.5 \mathrm{oz} / 100 \mathrm{gal}$ Outrider plus detergent at $0.12 \%$

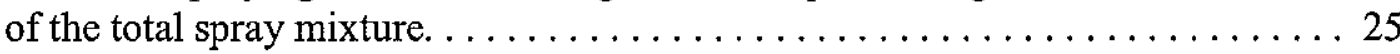


Figure 12. Same area as Figure 11 photographed on August 17, 2008 one year after spraying. Control of both mowed and unmowed Johnsongrass was $90 \%$. . 25

Figure 13. 2007 Implementation Trial in Uniform Test Area adjacent to US $63 \mathrm{~S}$ at intersection with US $36 \mathrm{~W}$. The Johnsongrass was about 5 feet tall and in flower. The Johnsongrass was sprayed on September 10, 2007 with $0.5 \mathrm{oz}$. Outrider per $100 \mathrm{gal}+$ detergent at $0.12 \%$ of the total spray mixture .27

Figure 14. The same area as shown in Figure 13 photographed on July 19, 2008 one year after spraying. The Johnsongrass was completely controlled. . . . . . . 27 


\section{TABLE OF TABLES}

Table 1. Summary of Data, 2004 Field Trials........................ 6

Table 2. Summary of Data, 2005 Field Trials........................ 7

Table 3. Summary of Data, 2006 Field Trials. ...................... $8-9$

Table 4. Summary of Data, 2007 Field Trials. ........................ 10-11

Table 5. Summary of Data, 2008 Field Trials. . . . . . . . . . . . . . . . . . 12-13

Table 6. Summary of treatments to compare Outrider alone, Roundup alone and Outrider + Roundup applied together or separately in 2004 and 2005 field studies. 14

Table 7. Effect of mowing on Johnsongrass control from the recommended spray mixture of $0.5 \mathrm{oz}$ Outrider $/ 100$ gal water plus $0.12 \%$ of total spray mixture of detergent sprayed to point of runoff. Johnsongrass growth stage was boot to early anthesis.

Table 8. Effect of developmental stage of Johnsongrass to spot treatment with Outrider. Outrider mixed at a rate of $1 \mathrm{oz} / 100$ gal plus detergent at $0.12 \%$ of the total spray mixture was applied at the point of runoff. . .

Table 9. Effect of detergent $\ldots \ldots \ldots \ldots \ldots \ldots \ldots \ldots \ldots \ldots \ldots \ldots \ldots \ldots \ldots \ldots, 26$ 


\section{1) IDENTIFICATION}

a) Title: CREATION OF A COMMITTED JOHNSONGRASS RESEARCH TEST AREA AND IMPLEMENTATION STUDY

b) Organization: Department of Medicinal Chemistry \& Molecular Pharmacology

Purdue University

West Lafayette, IN 47907

c) Principal Investigator: D. James Morré, Dow Distinguished Professor

d) Starting Date: August 1, 2004

2) INTRODUCTION

Johnsongrass eradication (control) has traditionally been one of the most difficult weed control problems in both crop and non-crop situations. Some materials, effective on seedling Johnsongrass in cropland are of limited effectiveness on established Johnsongrass along roadsides. At present, Johnsongrass represents the last major roadside weak problem for which no satisfactory recommendation exists for its control.

This project is based on a new candidate herbicide, Outrider, identified in a previous completed project (1), which has the potential to eradicate Johnsongrass when applied to mature growth or regrowth following mowing. The material does not harm oversprayed established fescue or bluegrass. Use as a spot treatment is anticipated due to cost and greater effectiveness.

A cold-adapted Johnsongrass ecotype identified in the Northern-most tier of counties in Indiana which provides a further threat of encroachment of roadside-established Johnsongrass onto adjacent cropland of considerable potential economic consequence also was studied.

\section{3) STATEMENT OF PROBLEM}

As Johnsongrass is a noxious weed, its control is dictated by law. Roadside Johnsongrass must be controlled. There are no alternatives. There are an estimated $4,000 \mathrm{ha}(10,000 \mathrm{acres})$ of Johnsongrass-infected roadsides within the roadside maintenance programs of the Districts in the southern 1/3 to 1/2 of the State of Indiana. Current costs of mowing and herbicide treatment are estimated to exceed $\$ 300,000$ and $\$ 500,000$ annually.

Johnsongrass is an introduced perennial warm-season grass (2) that is robust (up to $6 \mathrm{ft}$ tall) with dense foliage and limited in its habitat only by winter temperature (2-4). Even here, temperature limitation may no longer apply. We have described extensive acreages of roadside and crop land infestations of Johnsongrass near the Indiana-Michigan border that successfully over winter in the extreme north of Indiana. Johnsongrass is a superb competitor and usually overpowers other forms of roadside vegetation. It spreads both by rhizomes and by seed $(5,6)$.

While mowing will prevent reseeding, slow spread from rhizomes and maintain sight distances and appearance, mowing does not result in reduced infestations. There are no known natural diseases, pests or possibilities for biological control although recent attempts have been 
reported (7). In order to reduce Johnsongrass infestations, herbicide treatments have been traditionally employed $(8,9)$.

In the preparation of a comprehensive program of roadside maintenance and recommendation (mowing and spraying) for Indiana roadsides, current herbicide treatments were evaluated and found to be only partially effective for Johnsongrass. Of the materials available when this project was initiated, none were labeled for non-crop control of Johnsongrass. Roundup has been only partially effective in achieving Johnsongrass control with material applied at label rates. Even with repeated spraying, the Johnson grass persists.

Chemicals effective on Johnsongrass, commercially produced, registered for non-crop applications and available for roadside use, are few at present. Horizon, one of the materials used successfully earlier in the program, is no longer available in a form labeled for non-crop use. It is also very expensive (\$108/1; $\$ 400 /$ gal.).

Johnsongrass eradication (control) has traditionally been one of the most difficult weed control problems in both crop and non-crop situations. Materials effective on seedling Johnsongrass in cropland are ineffective on established Johnsongrass along roadsides. At present, Johnsongrass represents the last major roadside weed problem for which no satisfactory recommendation for control exists.

\section{4) OBJECTIVES}

The objectives of the research are to provide for eradication (control) of Johnsongrass along Indiana roadsides and to reduce current costs of maintenance by at least $\$ 100,000$ annually by reducing the need for mowing and by eliminating repeat applications of expensive, ineffective herbicides.

The products of the research will include the following:

- A cost effective program of Johnson grass eradication (control) using a herbicide treatment in combination with regular mowing cycles.

- Cost savings in excess of $\$ 100,000$ annually.

- An evaluation of the environmental and applicator safety of the practices recommended.

- An implementation plan for moving the results into practice.

\section{5) METHODS}

The major effort of the extended project will be to create and utilize the committed roadside Johnson grass research area where State and contractual activities would be carefully regulated. In addition the research efforts during the study will involve both field (spring, summer and fall) and laboratory (during winter months) studies.

The project was divided into two phases with specific tasks to be accomplished in each phase.

PHASE I. Field Evaluations for Efficacy

Phase I involved a recommendation of the SAC Committee to create a committed 
roadside Johnson grass research area with controlled mowing and date of spraying. The recommended area initially selected is US 63 from Jct. I 74 south to Jct. US 36 (Figs. 1 and 2). This is a moderately low traffic highway and centrally located. Johnson grass is abundant. The roadsides are fenced so that adjacent landowners cannot interfere. State and contractual activities would be carefully regulated and selected no mow and no spray areas would be posted. This was probably imperative if we were to achieve our goal of evaluating a new state-wide recommendation for chemical control of Johnson grass control.

PHASE II. Implementation

The implementation phase will consist of formulating a Johnson grass control strategy based on findings and testing and disseminating the recommendation.

Task 1. Formulation of Johnsongrass control recommendation

Based on the research findings a recommendation will be formulated for dissemination and final evaluation.

Task 2. Testing of final recommendation

The final recommendation will be disseminated to each of the districts concerned with Johnson grass control and evaluated for efficacy.

Task 3. Adoption of Johnson grass control policy

If the findings are successfully implemented, the recommendations will be disseminated for Statewide adoption and utilization for Johnson grass eradication (control).

Task 4. Preparation of summary report

The recommendations based on findings will be disseminated for validation and adoption in each of the Districts involved with Johnsongrass control. When implemented the results will provide for reduced maintenance costs by reducing the need for mowing and for the elimination of repeat herbicide applications. Cost savings in excess of $\$ 100,000$ annually are anticipated.

The research program was directed and conducted by D. James Morré, Professor of Medicinal Chemistry, Purdue University. During the course of the project a close working relationship was maintained with the members of the Study Advisory Committee, as well as the personnel from the Operations Division of the Indiana Department of Transportation.

The implementation phase began in 2006. Since efficacy of Johnsongrass control treatments are based on regrowth the next season following treatment, at least two years are required to evaluate the efficacy of any treatment to be evaluated in the study. As a result the project will not be completed before evaluation of 2008 field trials on or about the actual completion date of the project of July 31, 2009.

All treatments were tank mixed and applied using a singe nozzle (spraying systems 004) hand operates sprayer at $40 \mathrm{lbs}$. pressure. Broadcast applications were at $40 \mathrm{gpa}$. Spot treatments were to point of runoff. 


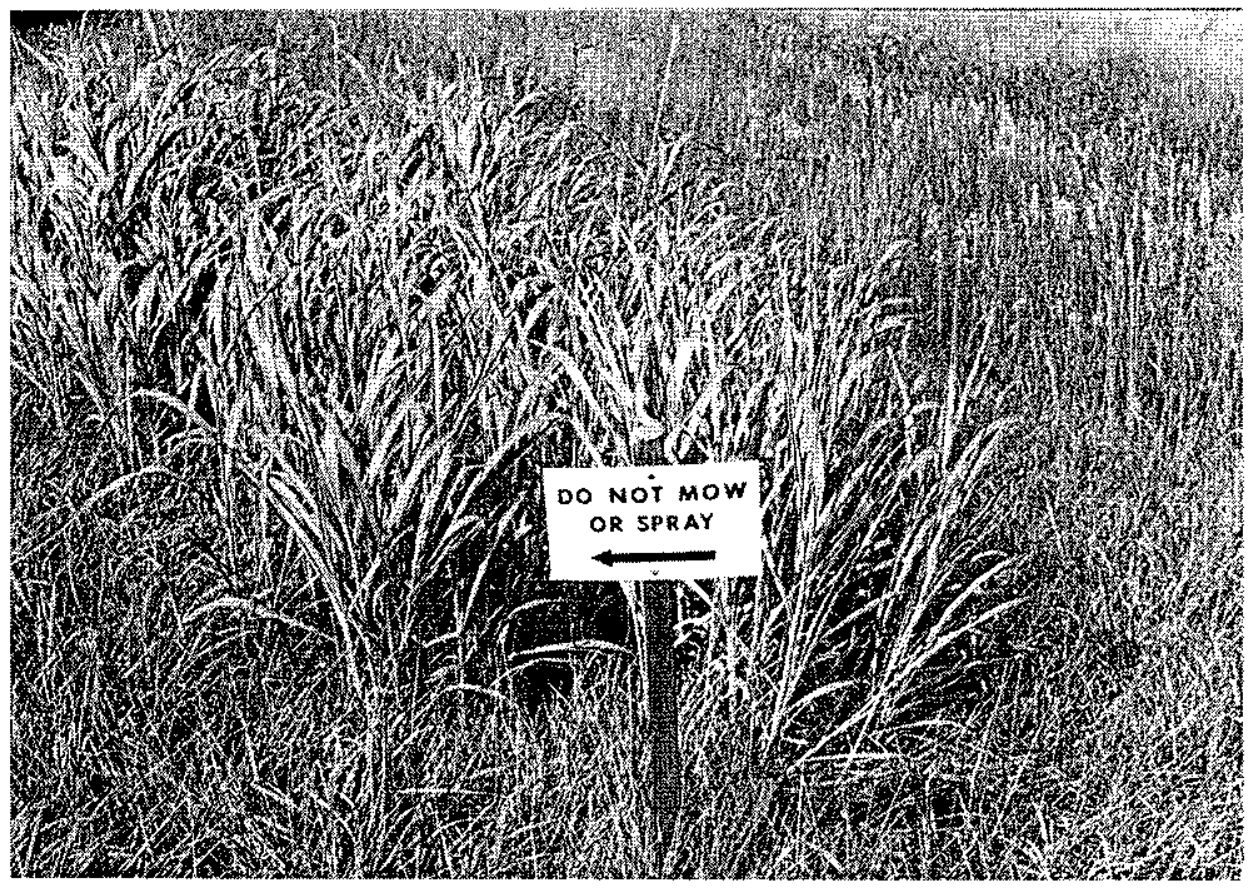

Figure 1. Uniform test area on US 63 north of Vermillion River. Johnsongrass was 48 inches tall. Photographed August 30, 2005 prior to spraying.

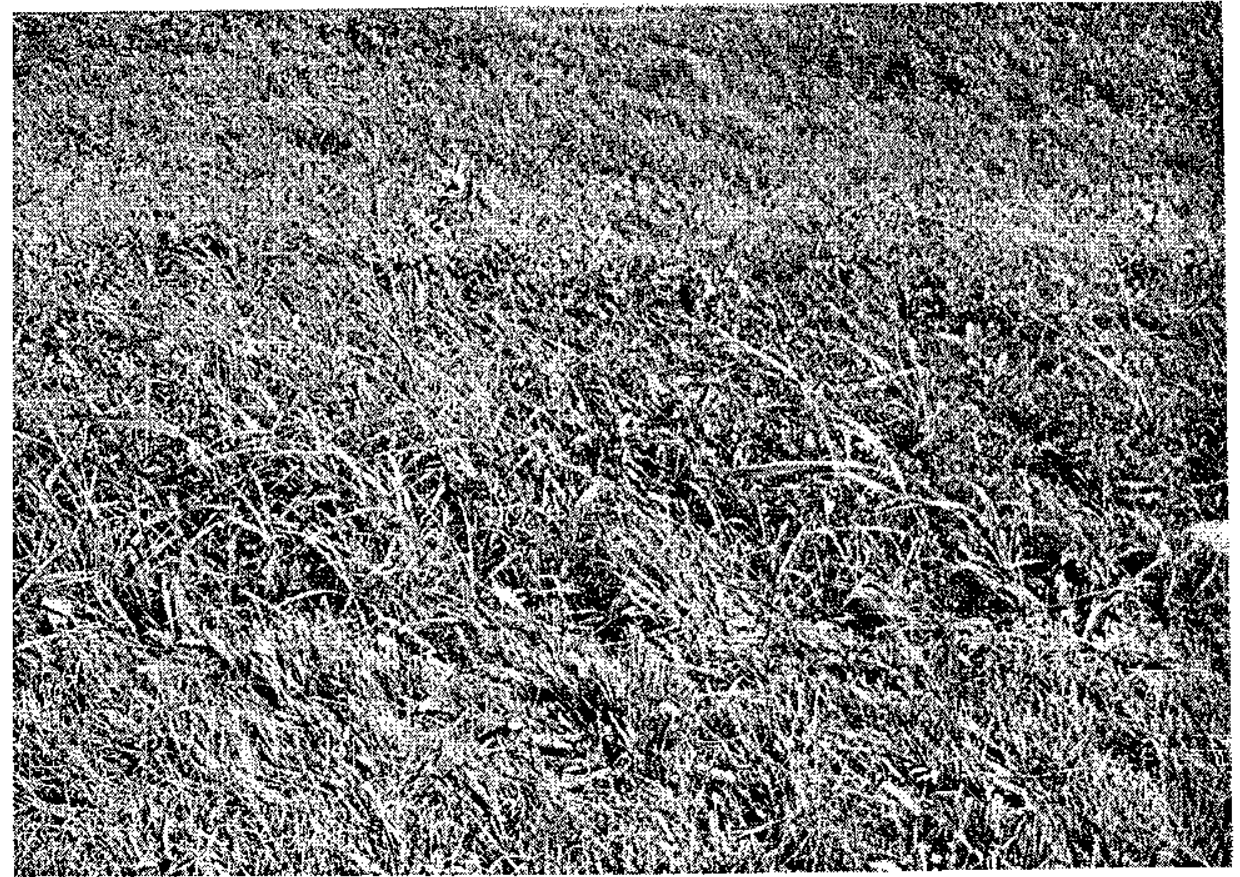

Figure 2. Uniform test area on US 63 north of Vermillion River photographed on September 29, 2006 one year after spraying with a broadcast application of $1 \mathrm{oz} / \mathrm{A}$ of Outrider plus detergent at $0.12 \%$ of the total spray mixture. 
At issue was the implementation stage of the project. Despite numerous attempts, we have only limited data uncomplicated by inadvertent mowing or spraying with Roundup by state maintenance crews or mowing or spraying with Roundup by adjacent land owners (getting permission to treat and asking them not to spray has only worsened the situation).

\section{6) RESULTS}

The project was begun August 1, 2004 with insufficient time for no more than a small number of initial field trials (Table 1). However, spraying and implementation trials and final evaluations of treatment applied in 2005 were completed on schedule (Table 2). In 2006, 24 new trials were established, more than half utilizing the uniform test area on US 63 (Table 3). The near optimum spray date for treating regrowth at the end of September was combined with a stage of growth study with Johnsongrass 24 to 30" tall, 33-36" tall and 40-42" tall without seed heads, seed heads forming in the boot, early anthesis (flowering), late flowering or with seed heads formed and 50-60" tall.

Fall 2006 marked initiation of the final implementation phase of the project. Outrider alone at a rate of $0.5 \mathrm{oz} / 100$ gal. plus a detergent at $0.12 \%$ of the total spray mixture spot sprayed to the point of runoff was tested in 2007 and again in 2008 as a possible recommendation. Treatments were restricted to regrowth following mowing. Evaluated in 2007 was a determination of the optimum regrowth stage to treat and the response to mowing following spraying (Table 4). Implementation questions to be answered in 2007 were how soon after spraying could the Johnsongrass be mowed without loss of treatment effectiveness and what will be the optimum interval between spraying and mowing for Johnsongrass eradication.

In 2008, the 2007 field trials were evaluated. In 2008 trials (Table 5), emphasis was on answering the question of how soon after spraying can the Johnsongrass be mowed without loss of treatment effectiveness and what will be the optimum interval between spraying and mowing for Johnsongrass eradication. Early evaluations of regrowth suggest that the interval between spraying and mowing can be very short (perhaps even as short as a matter of a few hours). The minimal interval may be one day or less.

New work in 2008 focused on which stage of regrowth was optimal for eradication of Johnsongrass by the Outrider application. Preliminary indications are that early boot through late seed head stages are equivalent. However, very early and very late stages of regrowth were under represented in the data. Trials were initiated in 2008 to confirm the findings in 2006 and 2007 and to fill in the regrowth stages under represented in the 2006 and 2007 studies. Also evaluated were studies of the effect of early and repeated mowing on Outrider effectiveness as encountered on roadsides maintained by adjacent property owners. Evaluations of 2008 studies will be completed prior to July 31, 2009.

\section{Effect of Roundup}

Completed in 2006 was a study with Roundup alone and in combination with Outrider either as a tank mix or sequentially with Roundup followed after several weeks by Outrider or Outrider followed after several weeks by Roundup comparing different rates, dates of application and stages of development (Fig. 5; Table 6). Completed was a 3-year study with Roundup alone and in combination with Outrider either as a tank mix or sequentially with Roundup followed 
after several weeks by Outrider or Outrider followed after several weeks by Roundup comparing different rates, dates of application and stages of development was completed. Roundup alone or in sequence several weeks following Outrider was without effect on Johnsongrass regrowth. A small benefit from $0.4 \mathrm{lb} / \mathrm{A}$ Roundup 3 to 6 weeks post Outrider was insufficient to justify the additional cost and offered no benefit over post Outrider mowing at the same stage. Correlations were with stage of growth with Johnsongrass 24 to 30" tall, 33-36: tall and 40-42" tall without seed heads, seed heads forming in the boot, early anthesis (flowering), late flowering or with seed heads formed and 50-60" tall and spray date.

TABLE 1

SUMMARY OF DATA - 2004 FIELD TRIALS

\begin{tabular}{|l|c|c|l|l|l|} 
Expt. & \multicolumn{1}{c}{ Spray Date } & \multicolumn{1}{c}{ Data } & \multicolumn{1}{c}{ Height } & \multicolumn{1}{c|}{ Stage } & Control \\
\hline $04-01$ & $8 / 11 / 04$ & $7 / 4 / 05$ & $44^{\prime \prime}$ & Anthesis & $86 \% 0.5 \mathrm{oz} / \mathrm{A}$ \\
\hline $04-02$ & $8 / 11 / 04$ & $7 / 4 / 05$ & $12-38^{\prime \prime}$ & Early seed head & $\begin{array}{c}\text { Outrider } 100 \% \\
\text { Roundup 0\% }\end{array}$ \\
\hline $04-03$ & $8 / 23 / 04$ & $6 / 9 / 05$ & $\begin{array}{l}20 " \\
6-9 \mathrm{ft} .\end{array}$ & $\begin{array}{l}\text { Mowed regrowth } \\
\text { Unmowed }\end{array}$ & $\begin{array}{l}100 \% \text { at } 0.75 \mathrm{oz} / \mathrm{A} \\
\text { Roundup - No effect }\end{array}$ \\
\hline
\end{tabular}


TABLE 2

SUMMARY OF DATA - 2005 FIELD TRIALS

\begin{tabular}{|c|c|c|c|c|c|}
\hline Expt. & Spray Date & Data & Height & Stage & Control \\
\hline $05-01$ & $5 / 28 / 05$ & $7 / 4$ & Short $\pm 6 "$ & & $50 \%$ \\
\hline $05-03$ & $7 / 4 / 05$ & $6 / 2 / 06$ & $38^{\prime \prime}$ & Early anthesis & $100 \%$ \\
\hline $05-04 \mathrm{~A}$ & $7 / 4 / 05$ & & $15-18$ " regrowth & & \\
\hline 05-04B & $8 / 3 / 05$ & & Not flowering & & \\
\hline $05-05$ & $8 / 3 / 05$ & $5 / 3 / 04$ & $68 "$ & Early anthesis & $100 \%$ \\
\hline 05-06 & & & $66^{\prime \prime}$ & $\begin{array}{l}\text { Early anthesis } \\
1 \text { oz. Outrider }\end{array}$ & $70 \%$ \\
\hline 05-07 & & & $24-28$ " regrowth & $\begin{array}{l}1 \text { oz. Outrider } \\
\text { sprayed } 2 X\end{array}$ & $91 \%$ \\
\hline $05-08$ & & $8 / 3 / 05$ & & $\begin{array}{l}\text { Early anthesis, } 1 \\
\text { oz. Outrider } \\
\text { Short } 50 / 250 \\
\text { Early anthesis }\end{array}$ & $\begin{array}{l}80 \% \\
78 \%\end{array}$ \\
\hline $05-10$ & $8 / 3 / 05$ & & $72 "$ & Early anthesis & $60 \%$ \\
\hline $05-11$ & $8 / 7 / 05$ & & $\begin{array}{l}\text { Mowed - 18-24" }-6 / 36 \\
\text { Unmowed - } 72 "\end{array}$ & Early anthesis & $\begin{array}{l}83 \% \\
36 \%\end{array}$ \\
\hline $05-12 \mathrm{~A}$ & $8 / 7 / 05$ & & Roundup then Outrider & & \\
\hline $05-13 \mathrm{~A}$ & & & Mixture & & \\
\hline $05-14 \mathrm{~A}$ & & & Mixture & & \\
\hline 05-11B & $8 / 23 / 05$ & & $34-46 "$ & Early anthesis & $90 \%$ \\
\hline $05-12 B$ & $8 / 23 / 05$ & & $72 "$ & Early anthesis & $60 \%$ \\
\hline $05-13 B$ & & & Not rated & & \\
\hline
\end{tabular}




\section{TABLE 3}

SUMMARY OF DATA - 2006 FIELD TRIALS

\begin{tabular}{|c|c|c|c|c|c|}
\hline Expt. & Spray Date & Data & Height & Stage & Control \\
\hline $06-01$ & $6 / 3 / 06$ & $8 / 15 / 07$ & $16 "$ & Early & $97 \% 0.75 \mathrm{oz} / \mathrm{A}$ \\
\hline $06-02$ & $6 / 3 / 06$ & $8 / 15 / 07$ & $12 "$ & Early & $\begin{array}{c}90 \% 0.5 \mathrm{oz} / \mathrm{A} \\
\text { Outrider + rRoundup } \\
\text { No effect }\end{array}$ \\
\hline $06-03$ & $6 / 3 / 06$ & $8 / 15 / 07$ & $12 "$ & Early & $\begin{array}{c}87 \% \text { at } 0.5 \mathrm{oz} / \mathrm{A} \\
\text { Roundup - No effect }\end{array}$ \\
\hline $06-04$ & $7 / 2 / 06$ & $8 / 15 / 07$ & $26-36 "$ & No seed heads & $50 \%$ at $0.5 \mathrm{oz} / \mathrm{A}$ \\
\hline 06-05 & $7 / 2 / 06$ & $8 / 15 / 07$ & $24-36 "$ & Infloresence in boot & $\begin{array}{c}30 \% \text { at } 0.5 \mathrm{oz} / \mathrm{A} \text { with } \\
\text { Roundup }\end{array}$ \\
\hline $06-06$ & $7 / 5 / 06$ & $8 / 16 / 07$ & $32 "$ & Infloresence in boot & $100 \%$ \\
\hline 06-07 & $8 / 1 / 06$ & $8 / 15 / 07$ & $56 "$ & Early anthesis & $50 \%$ at $1 \mathrm{oz} / \mathrm{A}$ \\
\hline $06-08$ & $8 / 1 / 06$ & $8 / 15 / 07$ & $56 "$ & Early anthesis & $78 \%$ at $0.75 \mathrm{oz} / \mathrm{A}$ \\
\hline 06-09 & $8 / 1 / 06$ & $8 / 15 / 07$ & $60^{\prime \prime}$ & Early anthesis & $\begin{array}{l}\text { Roundup 1-3 b/A } \\
\text { No control }\end{array}$ \\
\hline $06-10$ & $8 / 15 / 06$ & $7 / 12 / 07$ & $30-36 "$ & $\begin{array}{l}\text { Regrowth; no seed } \\
\text { heads forming }\end{array}$ & $100 \%$ \\
\hline $06-11$ & $8 / 15 / 06$ & $7 / 12 / 07$ & $52 "$ & Seed heads & 100 \\
\hline $06-12$ & $8 / 15 / 06$ & $7 / 31 / 07$ & $5-6 \mathrm{ft}$. & $\begin{array}{l}\text { Late anthesis } \\
12-16 \text { " regrowth }\end{array}$ & $90-100 \%$ \\
\hline $06-13$ & $8 / 15 / 06$ & $7 / 31 / 07$ & $5-6 \mathrm{ft}$. & $\begin{array}{l}\text { Late anthesis } \\
12-16 \text { " regrowth }\end{array}$ & $50 \%$ \\
\hline $06-14$ & $8 / 15 / 06$ & $7 / 31 / 07$ & $6 \mathrm{ft}$. & Anthesis & $98 \%$ \\
\hline $06-15$ & $8 / 15 / 06$ & $7 / 31 / 07$ & $5 \mathrm{ft}$. & Anthesis & $100 \%$ \\
\hline $06-16$ & $8 / 21 / 06$ & $6 / 12 / 07$ & $6 \mathrm{ft}$. & Seed heads & $93-100 \%$ \\
\hline $06-17$ & $9 / 9 / 06$ & $11 / 17 / 07$ & $20-30 "$ & Mowed regrowth & $93 \%$ \\
\hline
\end{tabular}




\begin{tabular}{|c|c|c|c|c|c|}
\hline $06-18$ & $9 / 11 / 06$ & $7 / 31 / 07$ & $30-36 "$ & $\begin{array}{l}\text { Unmowed; some in } \\
\text { anthesis }\end{array}$ & $92 \%$ \\
\hline $06-19$ & $9 / 11 / 06$ & $7 / 12 / 07$ & $24 "$ & Regrowth & $89 \%$ \\
\hline $06-20$ & $9 / 12 / 06$ & $10 / 10 / 06$ & $20 "$ & Regrowth & Dying \\
\hline $06-21$ & $9 / 12 / 06$ & $7 / 31 / 07$ & $20 "$ & Regrowth & $90 \%$ \\
\hline $06-22$ & $9 / 29 / 06$ & $7 / 12 / 07$ & $36 "$ & Regrowth & $100 \%$ \\
\hline $06-23$ & $9 / 29 / 06$ & $7 / 12 / 07$ & $\begin{array}{l}20-24 " \\
3-4 \mathrm{ft} . \\
5 \mathrm{ft} .\end{array}$ & $\begin{array}{l}\text { Regrowth } \\
\text { Early anthesis/boot } \\
\text { Seed heads }\end{array}$ & $\begin{array}{c}\text { None } \\
75 \% \\
100 \% \\
\end{array}$ \\
\hline
\end{tabular}


Table 4

SUMMARY OF DATA - 2007 FIELD TRIALS

\begin{tabular}{|c|c|c|c|c|}
\hline Expt. & Spray Dat & Height & Stage & Control \\
\hline $07 / 01$ & $7 / 12 / 07$ & 50 " regrowth & No seed heads & $94 \%$ \\
\hline 07/01 & $7 / 12 / 07$ & $\begin{array}{l}5-6 \mathrm{ft} \text { unmowed } \\
\text { Front mowed } 19 \text { days after spraying }\end{array}$ & Early anthesis & $\begin{array}{l}100 \% \\
100 \%\end{array}$ \\
\hline $07 / 03$ & $7 / 12 / 07$ & 36 " regrowth & $\begin{array}{l}\text { Boot } \\
\text { Boot to early anthesis }\end{array}$ & $\begin{array}{l}98 \% \\
90 \%\end{array}$ \\
\hline $07 / 04$ & $7 / 12 / 07$ & 20 " to 30 " regrowth & No seed heads & $100 \%$ \\
\hline 07/05 & $7 / 31 / 07$ & $\begin{array}{l}36 " \text { regrowth } \\
30-61 \text { " regrowth } \\
34 \text { " regrowth }\end{array}$ & $\begin{array}{l}\text { No seedheads } \\
\text { Boot to early anthesis } \\
\text { No seed heads }\end{array}$ & $\begin{array}{c}84 \% \\
100 \% \\
96 \%\end{array}$ \\
\hline $07 / 06$ & $7 / 31 / 07$ & $36-72 \%$ unmowed & Early anthesis & $100 \%$ \\
\hline $07 / 07$ & $7 / 31 / 07$ & $>72$ " unmowed & Anthesis & $90 \%$ \\
\hline $07 / 08$ & $8 / 01 / 07$ & 40 " regrowth & $\begin{array}{l}\text { No seed heads, } 20-30 " \\
\text { boot to early anthesis }\end{array}$ & $\begin{array}{c}75 \% \\
100 \% \\
\end{array}$ \\
\hline $07 / 09$ & $8 / 01 / 07$ & 72" unmowed & Early anthesis & $100 \%$ \\
\hline $07 / 10$ & $8 / 15 / 07$ & $\begin{array}{l}6 \mathrm{ft} \text {. unmowed } \\
\text { Unmowed or mowed } 4 \mathrm{~h} \text { after } \\
\text { spraying }\end{array}$ & Early anthesis & $\begin{array}{c}95 \% \\
100 \%\end{array}$ \\
\hline $07 / 11$ & $8 / 15 / 07$ & $5 \mathrm{ft}$. unmowed & Early anthesis & $90 \%$ \\
\hline $07 / 12$ & $8 / 15 / 07$ & $46 "-6 \mathrm{ft}$. & Early anthesis & $100 \%$ \\
\hline $07 / 13$ & $8 / 15 / 07$ & $\begin{array}{l}6 \mathrm{ft} \text {. } \\
\text { Mowed } 1 \text { to } 5 \text { days after spraying }\end{array}$ & Anthesis & $93 \%$ \\
\hline $07 / 14$ & $8 / 16 / 07$ & $5-6 \mathrm{ft}$. & Seed heads not mowed & $0 \%$ \\
\hline $07 / 15$ & $8 / 26 / 07$ & $\begin{array}{l}30 \text { to } 36 " \text { regrowth } \\
40 \text { to } 72 \text { " regrowth }\end{array}$ & $\begin{array}{l}\text { No seed heads } \\
\text { Seed heads/early anthesis }\end{array}$ & $\begin{array}{l}85 \% \\
97 \% \\
\end{array}$ \\
\hline $07 / 16$ & $9 / 09 / 07$ & $61^{\prime \prime}$ & Seed heads & $98 \%$ \\
\hline
\end{tabular}




\begin{tabular}{|c|c|l|l|c|}
\hline $07 / 17$ & $9 / 09 / 07$ & $\begin{array}{l}\text { 10" regrowth } \\
\text { Mowed one week after spraying }\end{array}$ & $\begin{array}{c}\text { No } \\
\text { control }\end{array}$ \\
\hline $07 / 18$ & $9 / 09 / 07$ & $60 "$ & $\begin{array}{l}\text { Seed heads } \\
\text { Early anthesis }\end{array}$ & $\begin{array}{c}100 \% \\
60 \%\end{array}$ \\
\hline $07 / 19$ & $9 / 10 / 07$ & 40 to $50 "$ & & \\
\hline $07 / 20$ & $9 / 10 / 07$ & $16-18 "$ & No seed heads & $\begin{array}{c}\text { No } \\
\text { control }\end{array}$ \\
\hline
\end{tabular}


TABLE 5

SUMMARY OF DATA - 2008 FIELD TRIALS

\begin{tabular}{|c|c|c|c|c|c|}
\hline Expt. & Spray Date & Data & Height & Stage & Control \\
\hline 0801 & $6 / 21 / 08$ & & $16 "$ & Mowed regrowth & No regrowth \\
\hline 08-02 & $7 / 3 / 08$ & & $16 "$ & Mowed regrowth & No regrowth \\
\hline $08-03$ & $7 / 3 / 08$ & & 24-46" & Mowed regrowth & No regrowth \\
\hline $08-04$ & $7 / 17 / 08$ & & 56-72" & Boot to early flower & $90-100 \%$ \\
\hline 08-05 & $7 / 17 / 08$ & & $40^{\prime \prime}$ & $\begin{array}{l}\text { Boot regrowth from } \\
\text { early mowing }\end{array}$ & $98 \%$ \\
\hline $08-06$ & $7 / 17 / 08$ & & $68 ”$ & Early flower & $99 \%$ \\
\hline $08-07$ & $7 / 17 / 08$ & & $30 "$ & No seed heads & $92 \%$ \\
\hline 08-08 & $7 / 17 / 08$ & & $30-46^{\prime \prime}$ & $\begin{array}{l}\text { Boot mowed } \\
\text { regrowth }\end{array}$ & $95 \%$ \\
\hline 08-09 & $7 / 18 / 08$ & & $6-8 \mathrm{ft}$. & $\begin{array}{l}\text { Early-late anthesis. } \\
\text { Unmowed }\end{array}$ & No regrowth \\
\hline $08-10$ & $7 / 18 / 08$ & & $6-8 \mathrm{ft}$. & $\begin{array}{l}\text { Early-late anthesis. } \\
\text { Unmowed }\end{array}$ & $85 \%$ * \\
\hline $08-11$ & $7 / 29 / 08$ & & $48 "$ & $\begin{array}{l}\text { Late boot - early } \\
\text { anthesis. Regrowth. }\end{array}$ & No regrowth \\
\hline $08-12$ & $7 / 29 / 08$ & & $72 "$ & Mid-anthesis & No regrowth \\
\hline $08-13$ & $7 / 30 / 08$ & & $\begin{array}{l}36^{\prime} \\
75^{\prime \prime}\end{array}$ & $\begin{array}{l}\text { Boot. } \\
\text { Late anthesis }\end{array}$ & No regrowth \\
\hline $08-14$ & $7 / 30 / 08$ & & $6-10^{\prime \prime}$ & Freshly mowed & Ho regrowth \\
\hline $08-15$ & $8 / 10 / 08$ & & $\begin{array}{l}36 " \\
6 \mathrm{ft} .\end{array}$ & $\begin{array}{l}\text { No seed heads } \\
\text { Late anthesis }\end{array}$ & No regrowth \\
\hline $08-16$ & $8 / 10 / 08$ & & $6 \mathrm{ft}$. & Late anthesis & $97 \%$ \\
\hline $08-17$ & $8 / 10 / 08$ & & $24-40 "$ & No seed heads & No regrowth \\
\hline $08-18$ & 9/9/08 & & $30-36 "$ & Boot regrowth & $96 \%$ \\
\hline
\end{tabular}

* Sprayed with Roundup by DOT personnel before outrider could take effect 


\begin{tabular}{|l|l|l|l|l|c|}
\hline $08-19$ & $9 / 9 / 08$ & & $6 \mathrm{ft}$. & Early seed heads & $80 \%$ \\
\hline $08-20$ & $9 / 9 / 08$ & & $30 "$ & $\begin{array}{l}\text { Mowed regrowth } \\
\text { No seed heads }\end{array}$ & $98 \%$ \\
\hline $08-21$ & $9 / 17 / 08$ & & $22-36 "$ & $\begin{array}{l}\text { Mowed regrowth } \\
\text { No seed heads }\end{array}$ & No regrowth \\
\hline $08-22$ & $9 / 17 / 08$ & & $6-8 \mathrm{ft}$. & $\begin{array}{l}\text { Late anthesis } \\
\text { Early seed heads }\end{array}$ & $90 \%$ \\
\hline
\end{tabular}




\section{TABLE 6}

Summary of Treatments to Compare Outrider Alone, Roundup Alone and Outrider + Roundup Applied Together or Separately in 2004 and 2005 Field Studies

Outrider alone applied at $0.25,0.5,0.75$ and $1 \mathrm{oz} / \mathrm{A}$ with detergent as 0.12 or $0.25 \%$ of the total spray mixture.

Roundup applied alone at $0.1,0.2,0.3$ and $0.4 \mathrm{lb} / \mathrm{A}$ with detergent at 0.12 or $0.25 \%$ of the total spray mixture.

Outrider $(0.25 \mathrm{oz} / \mathrm{A})+$ Roundup $(0.1 \mathrm{lb} / \mathrm{A})$ in a tank mix with $0.12 \%$ detergent applied at $1 \mathrm{X}$, $2 \mathrm{X}, 3 \mathrm{X}$ and $4 \mathrm{X}$.

Roundup at the same rates as Roundup alone followed after 2 weeks by Outrider at the same rates as Outrider alone.

Outrider at the same rates as Roundup alone followed after 2, 3, 4 or 5 weeks later by Roundup at the same rates as Outrider alone. 


\section{Effect of mowing}

With few exceptions, Johnsongrass sprayed within roadside rights-of-way was mowed at least once following spraying. Since control under these conditions has generally been good (greater than $90 \%$ ), it is important to know that Johnsongrass can be mowed following treatment without loss of treatment effectiveness.

Questions unanswered by these general observations were the following:

Was mowing required for Johnsongrass control with Outrider? Or, if not required, was there benefit from mowing for Johnsongrass control with Outrider?

How soon after spraying or how long after spraying can mowing occur with no adverse effect on treatment effectiveness?

Two experiments in 2006 and ten (10) experiments in 2007 were directed toward answering these questions (Table 7).

Studies with unmowed Johnsongrass have been limited largely to fence rows (Fig. 3) and infestations behind guardrails on bridge approaches (Fig. 4) where opportunities for mechanical mowing are restricted. In two studies, one in 2006 and one in 2007, side-by-side comparisons indicated that it did not matter if the Johnsongrass was mowed or not mowed following spraying (Figs. 6-8). An exception was encountered in one experiment with Johnsongrass in late seed heads where the unmowed plots recovered completely whereas control was achieved with mowed plots. Overall control of unmowed Johnsongrass when sprayed in boot or early anthesis ranged from 50 to $100 \%$ (average $85 \%$ ). As to timing, more data are available from both 2006 and 2007 experiments. The shortest interval between spraying and mowing tested was 4 hours and control was $80 \%$ in one trial and $100 \%$ in the other (Table 1). On average, longer intervals ( 1 to 30 days) between spraying and mowing were approximately equivalent with no mowing and ranged from 89 to $100 \%$ (average $98 \%$ ) with no clear indication of an optimal interval (Table 1).

\section{Date of spraying}

The spraying season for Johnsongrass in Indiana is early June through early September. Johnsongrass is a tropical grass and emerges in late spring well behind fescue and other temperate grasses. Spraying of unmowed Johnsongrass in June is extremely difficult since the Johnsongrass is usually shorter than the surrounding fescue and spot treatments result in too many skips while a broadcast application becomes too costly.

For the most part, Johnsongrass treatment as a practical matter begins with regrowth following the first mowing. In 2005 using a broadcast application of $0.5 \mathrm{oz}$ Outrider/A (40 pga) plus $0.12 \%$ detergent in the spray mixture, regrowth, 20 to 40 inches tall, sprayed between June 24 and August 23, resulted in $95 \pm 8 \%$ control (Fig. 9). Broadcast spraying of later stages or unmowed Johnsongrass 60 to 80 inches tall between August 3 and August 23 resulted in $70 \pm$ $20 \%$ control (range 5-98\%). Part of the reduced control from the broadcast application to mature Johnsongrass was traced to inadequate coverage of the very tall Johnsongrass at which point the standard treatment practice was changed to a tank mix of $0.5 \mathrm{oz} / 100$ gal plus $0.12 \%$ detergent with spraying to point of run off. 


\section{TABLE 7}

Effect of mowing on Johnsongrass control from the recommended spray mixture of $0.5 \mathrm{oz}$ Outrider $/ 100$ gal water plus $0.12 \%$ of total spray mixture of detergent sprayed to point of runoff. Johnsongrass growth stage was boot to early anthesis.

Experiment Interval between spraying and mowing

Control

\begin{tabular}{|c|c|c|}
\hline $07-10$ & 4 hours & $100 \%$ \\
\hline $07-15$ & 4 hours & $80 \%$ \\
\hline $07-13$ & 1 day & $100 \%$ \\
\hline $07-15$ & 1 day & $100 \%$ \\
\hline $07-09$ & 4 days & $100 \%$ \\
\hline $07-15$ & 4 days & $80 \%$ \\
\hline $07-09$ & 5 days & $100 \%$ \\
\hline $07-15$ & 5 days & $89 \%$ \\
\hline $07-03$ & 6 days & $90 \%$ \\
\hline $07-16$ & 7 days & $98 \%$ \\
\hline $07-12$ & 11 days & $100 \%$ \\
\hline $06-16$ & $\begin{array}{l}7 \text { days } \\
14 \text { days }\end{array}$ & $\begin{array}{l}\text { No regrowth } \\
\text { No regrowth }\end{array}$ \\
\hline $07-02$ & 19 days & $100 \%$ \\
\hline $07-08$ & 30 days & $100 \%$ \\
\hline $07-02$ & Unmowed & $90 \%$ \\
\hline $07-03$ & Unmowed & $92 \%$ \\
\hline $07-07$ & Unmowed & $89 \%$ \\
\hline $07-14$ & Unmowed & $0 \%{ }^{*}$ \\
\hline
\end{tabular}




\begin{tabular}{|c|l|c|}
\hline $06-13$ & Unmowed & $50 \%$ \\
\hline $06-16$ & Unmowed & $100 \%$ \\
\hline
\end{tabular}

"Sprayed 8/26, $72 "$ with seed heads. If mowed same day, there was control.

In 2006, early regrowth 12-16 inches tall sprayed during the first week of June was adequately controlled. Regrowth of 24 to 35 inches was poorly controlled with broadcast applications of $0.5 \mathrm{oz} / \mathrm{A}$ Outrider and Johnsongrass in early anthesis 56 inches tall was also poorly controlled even at 0.75 or $1 \mathrm{oz} / \mathrm{A}$ of Outrider. After switching to the spot application with spraying to point of runoff, beginning in mid-August, Johnsongrass 4 to $6 \mathrm{ft}$ tall flowering (anthesis) or with seed heads was adequately controlled. Also reasonably well controlled was regrowth 20 to 30 inches tall sprayed during the first two weeks of September. Regrowth sprayed at the end of September 2006, 20-24 inches tall, was not controlled most likely due to early frost whereas more mature Johnsongrass (3-5 ft flowering or with seed heads) was controlled.

In 2007, spraying initiated in early July to regrowth 20-50 inches tall again regulated in adequate control (90 to $100 \%$ ). Applications the last week of July and the first week of August to 36 to 72 inches of regrowth were more variable (75 to $100 \%$ ) with best results from Johnsongrass sprayed with seed heads in the boot or emerging and flowering. Mid-August applications were also adequate to both mowed and unmowed Johnsongrass with control ranging from 90 to $100 \%$. Only one treatment using the spot treatment applied to Johnsongrass 5-6 ft. tall with seed heads failed to achieve significant control. Applications on September 9 to regrowth 10 to 18 inches tall were ineffective again most likely to early frost whereas mature Johnsongrass with seed heads was more adequately controlled (60 to $100 \%$ ).

Generally, with the spot treatments, the recommendation is to spray Johnsongrass to the point of runoff after it reaches a height of 24 to 40 inches after the first mowing in July or early August. Spraying of regrowth in late August or early September is not recommended. Unmowed or mowed Johnsongrass with seed heads forming, in flower or formed can be sprayed at any date in July or August or possibly even into the first two weeks of September with a reasonable probability of achieving at least $90 \%$ control.

\section{Developmental stage at time of spraying}

Comparing mid-season spray dates in 2006 and 2007 with the spot treatment of $1 \mathrm{oz}$ Outrider/100 gallons plus detergent at $0.12 \%$ of the total spray mixture applied to the point of runoff, treatments applied from the first week of July to the end of August, Johnsongrass in early to late flowering or with seed heads formed or forming was somewhat better controlled, on average, than mowed regrowth although the differences were not great ( $92 \%$ vs $97 \%$ control). Early September applications were generally less effective overall (79\% control) for both regrowth of Johnsongrass and Johnsongrass still in flower (Table 8). However, with Johnsongrass where seed heads were already formed, September applications provided control comparable to mid-season applications. 


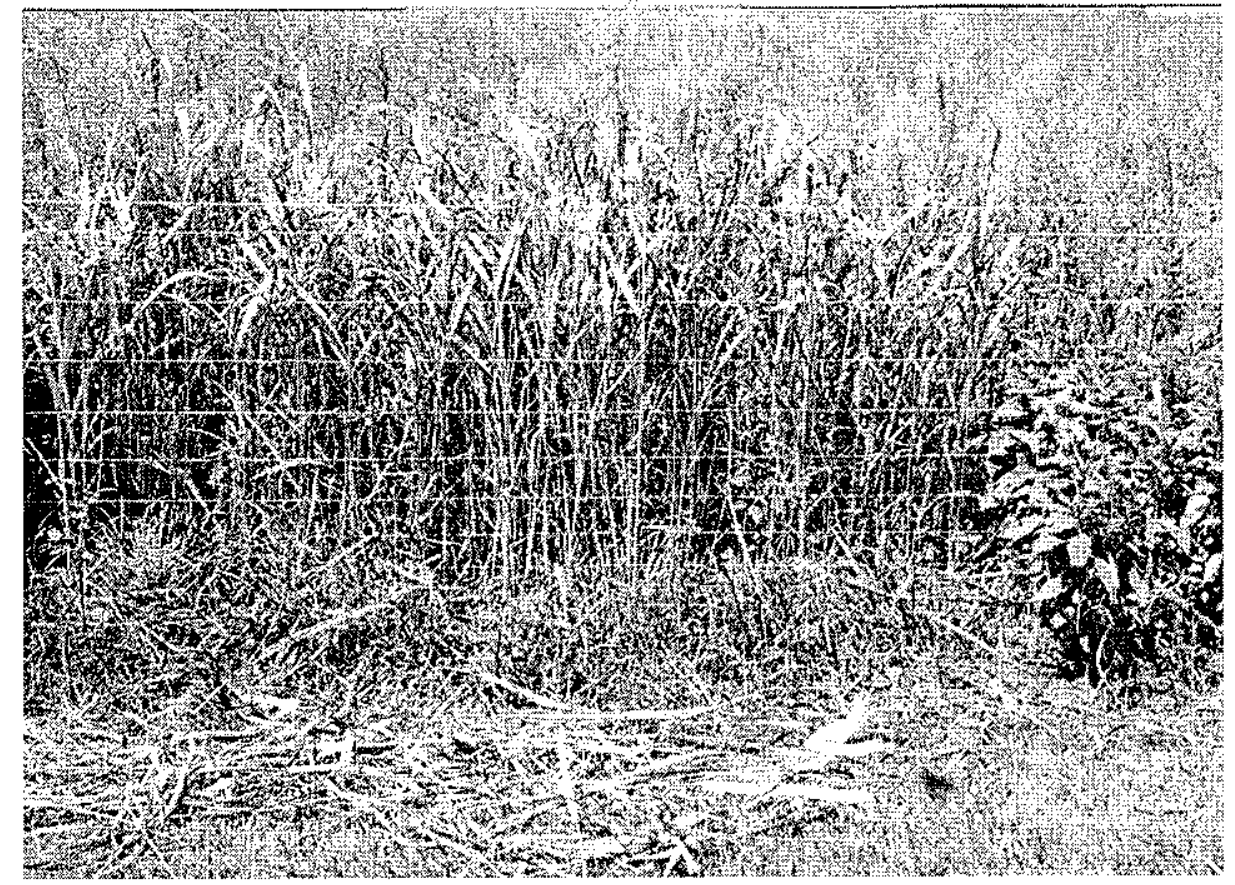

Figure 3. Unmowed mature Johnsongrass in a fence row on a side road adjacent to the Uniform Test Area on US $63 \mathrm{~N}$ just south of the Vermillion River. The Johnsongrass in the foreground was mowed as part of an experimental mowing trial.

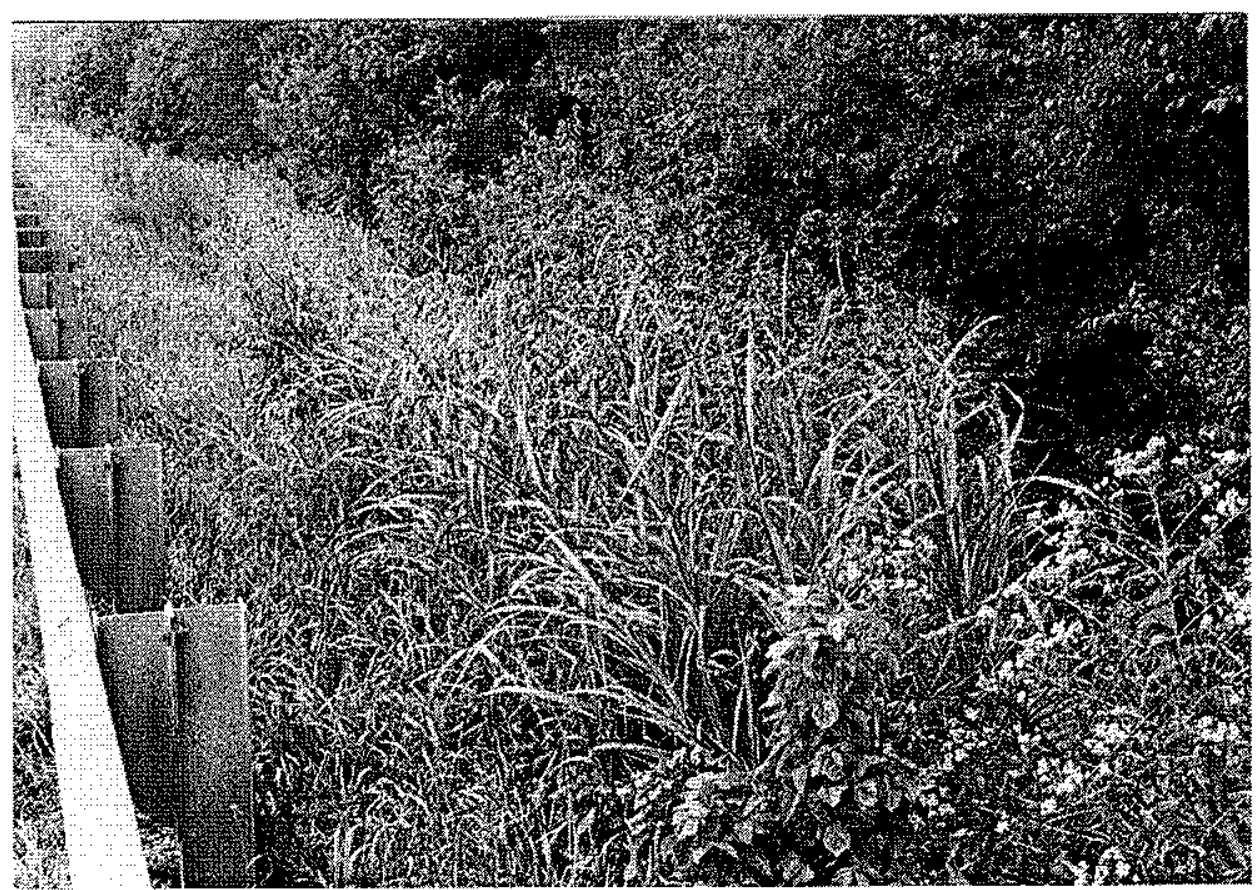

Figure 4. Unmowed mature Johnsongrass behind a guardrail on a bridge approach on I-70 north of the Wabash River bridge. Photographed August 23, 2005. 


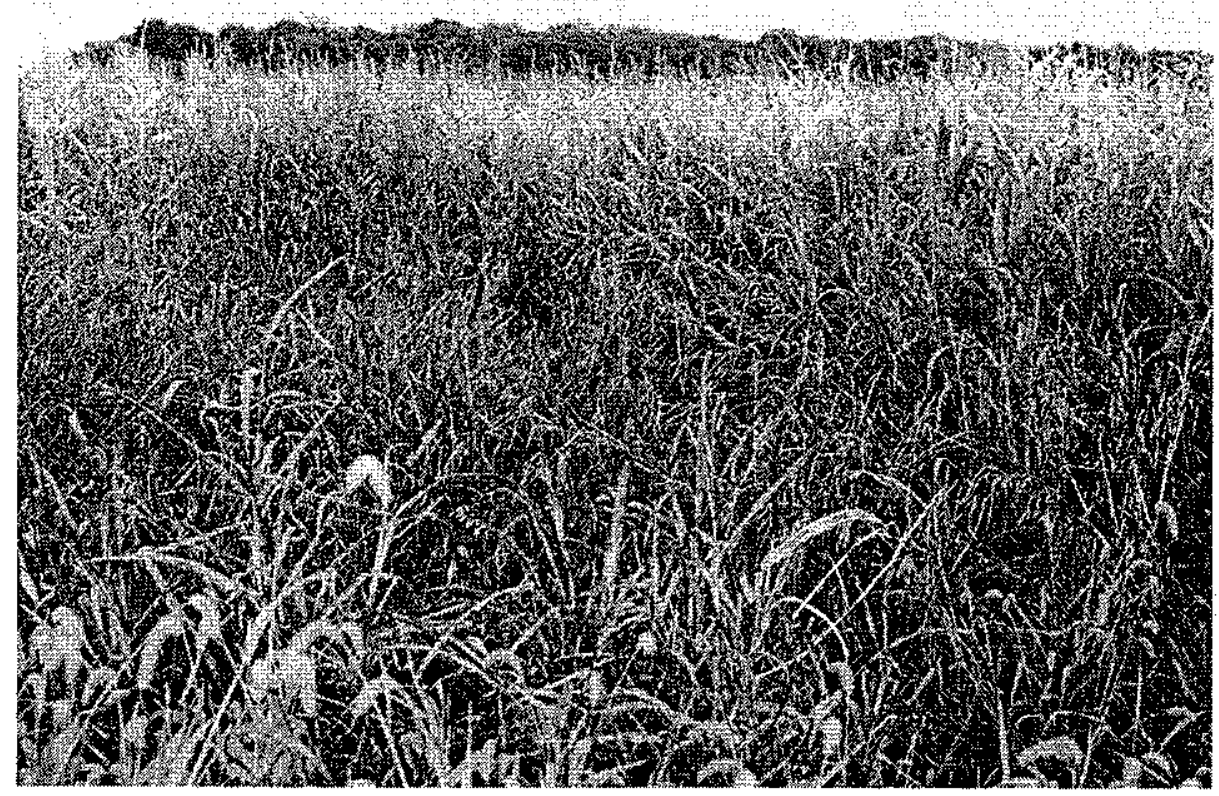

Figure 5. Johnsongrass in Northern Indiana Test Area adjacent to IN 123 between South Bend and New Liberty. The area in the foreground was sprayed with $0.2 \mathrm{lb} / \mathrm{A}$ Roundup on August 11, 2004. The area was photographed on September 16, 2004. Evaluations in August and September 2005 revealed no lasting control as a result of the application of Roundup.

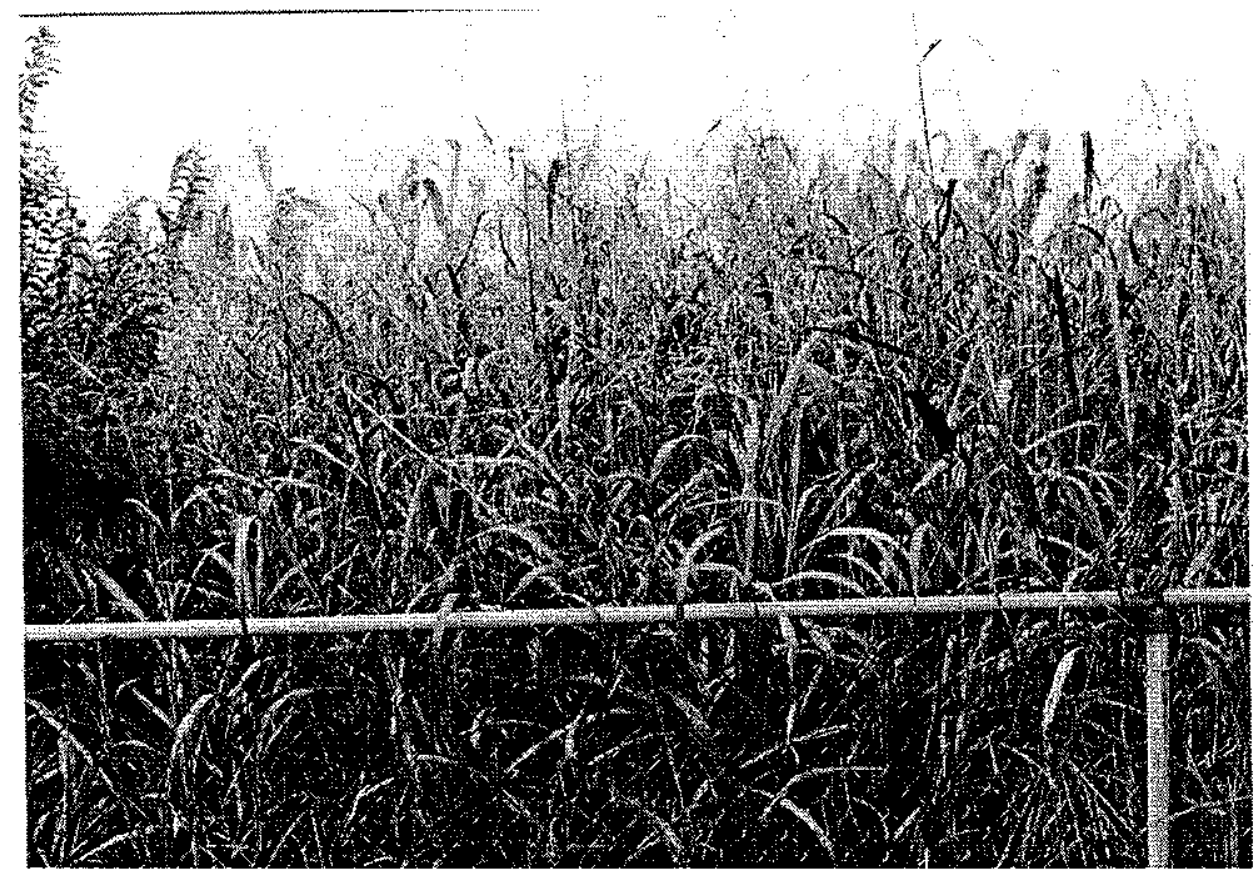

Figure 6. Unmowed mature Johnsongrass in a fence row on Old Romney Road near Lafayette, Indiana photographed on August 3, 2005 prior to spraying or mowing. 


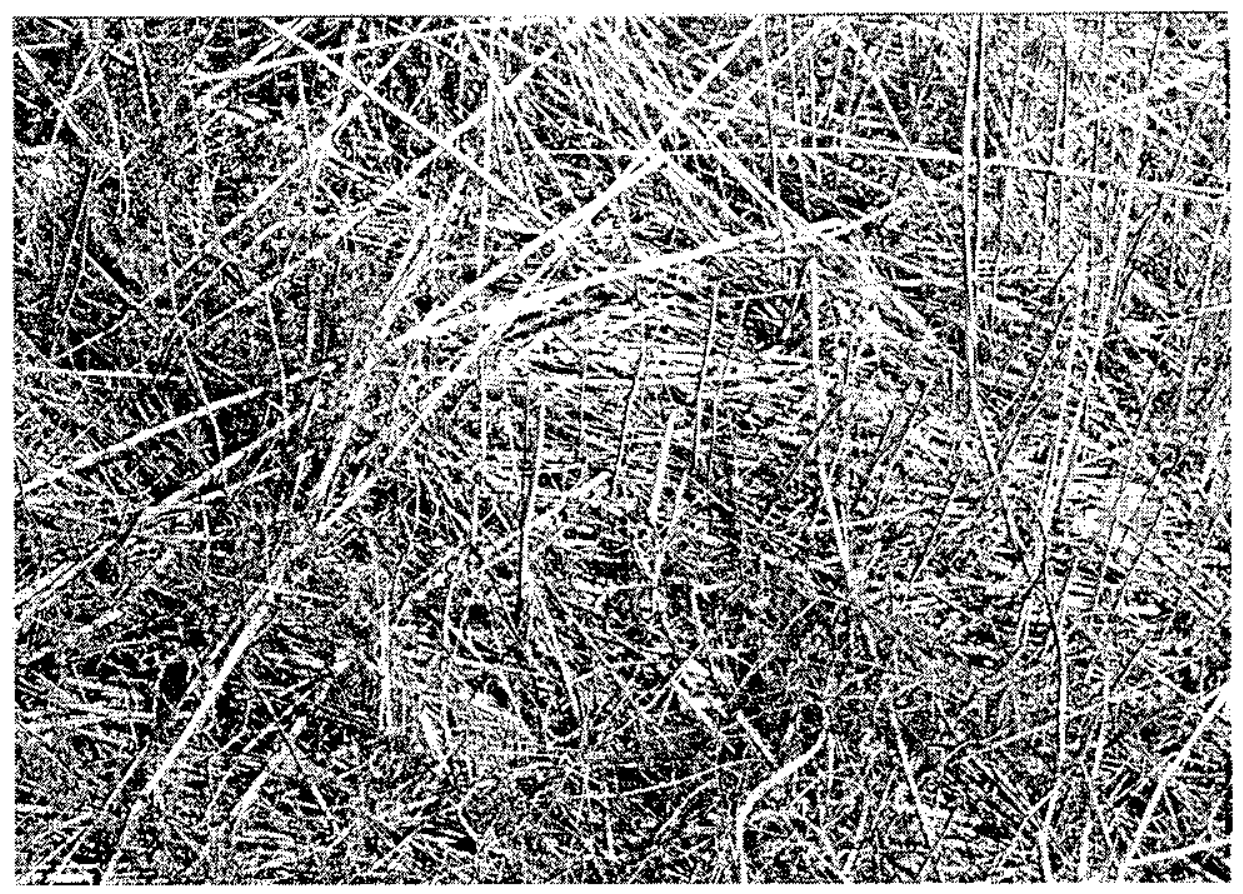

Figure 7. Area sprayed to point of runoff with $0.5 \mathrm{oz} / 100 \mathrm{gal}$ Outrider + detergent at $0.12 \%$ of the total spray mixture on August 3, 2005 with evaluation on June 12, 2007. The Johnsongrass was unmowed. Control was $100 \%$.

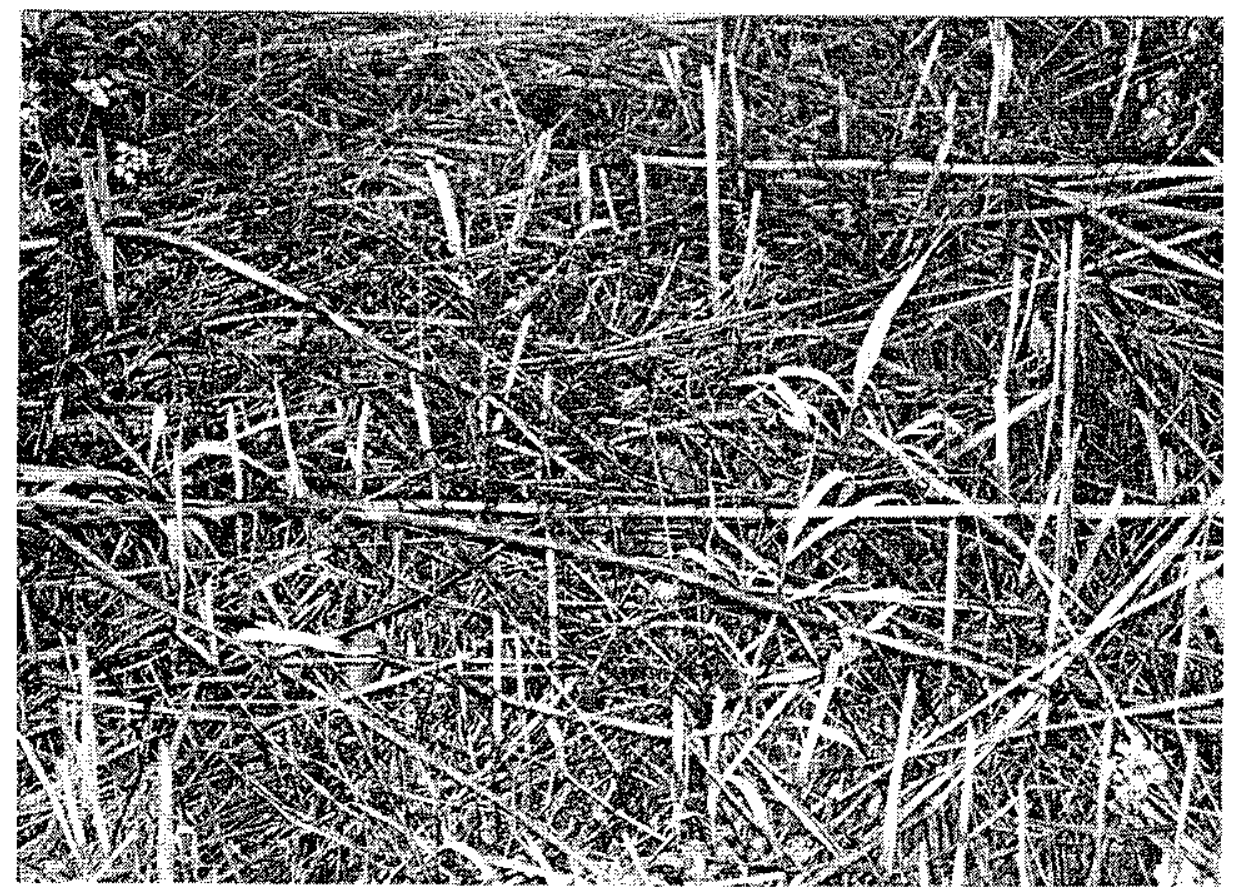

Figure 8. As in Figure 7 except that the Johnsongrass was mowed 2 weeks after spraying. Control was $>98 \%$. Photographed June 12, 2007. 


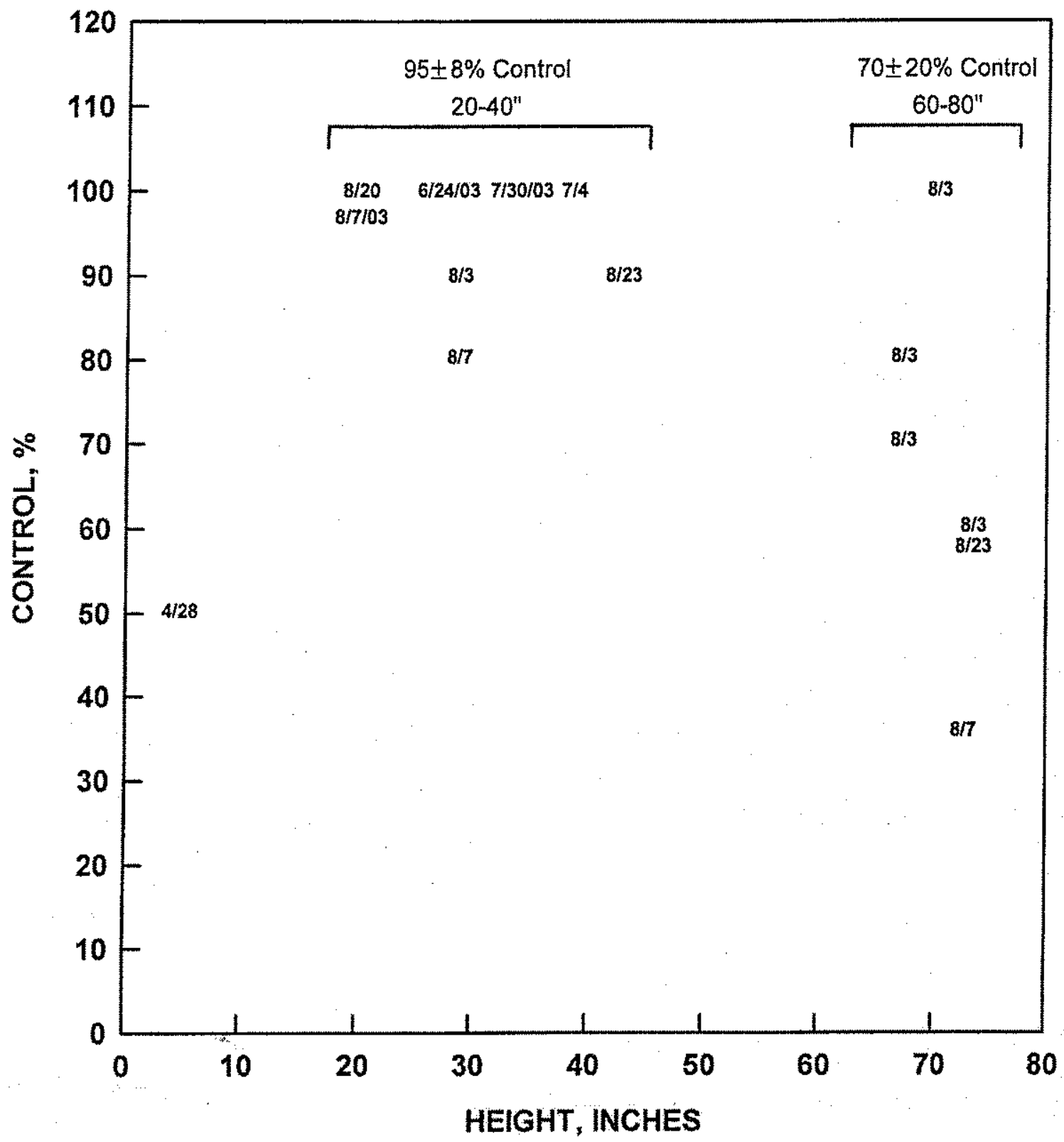

Figure 9. Correlation between Johnsongrass height at the time of application and percent control for a broadcast application of $1 \mathrm{oz} / \mathrm{A}$ Outrider plus detergent $(0.12 \%$ of total spray mixture) (40 gpa) in 2005 comparing different dates of application as indicated. 
TABLE 8

Effect of developmental stage of Johnsongrass to spot treatment with Outrider. Outrider mixed at a rate of $1 \mathrm{oz} / 100$ gallons plus detergent at $0.12 \%$ of the total spray mixture was applied at the point of runoff.

Growth Stage Height $\quad$ Spray Date Control

\begin{tabular}{|c|c|c|c|}
\hline $\begin{array}{c}\text { Vegetative (no seed heads) } \\
\text { Mowed regrowth }\end{array}$ & 20-36 inches & $\begin{array}{l}7 / 12 / 07 \\
7 / 03 / 07 \\
8 / 15 / 06 \\
8 / 26 / 07 \\
9 / 09 / 06 \\
9 / 11 / 06\end{array}$ & $\begin{array}{r}100 \% \\
84 \% \\
100 \% \\
85 \% \\
93 \% \\
89 \%\end{array}$ \\
\hline Seed heads forming in boot & 32-36 inches & $\begin{array}{l}7 / 05 / 06 \\
7 / 12 / 07 \\
\end{array}$ & $\begin{array}{r}100 \% \\
98 \% \\
\end{array}$ \\
\hline Early anthesis (early flowering) & $4-6 \mathrm{ft}$. & $\begin{array}{l}7 / 12 / 07 \\
8 / 01 / 07 \\
8 / 15 / 07 \\
8 / 26 / 07 \\
9 / 09 / 07 \\
9 / 11 / 06 \\
9 / 29 / 06\end{array}$ & $\begin{array}{r}90 \% \\
100 \% \\
100 \% \\
97 \% \\
60 \% \\
92 \% \\
75 \% \\
\end{array}$ \\
\hline Anthesis (flowering) & $4-6 \mathrm{ft}$. & $\begin{array}{l}8 / 15 / 06 \\
8 / 15 / 07\end{array}$ & $\begin{array}{l}98 \% \\
93 \%\end{array}$ \\
\hline Late anthesis (flowering) & $4-6 \mathrm{ft}$. & $\begin{array}{l}8 / 15 / 06 \\
8 / 26 / 07 \\
\end{array}$ & $\begin{array}{c}90-100 \% \\
97 \%\end{array}$ \\
\hline Seed heads & $4-6 \mathrm{ft}$. & $\begin{array}{l}8 / 15 / 06 \\
8 / 21 / 06 \\
9 / 09 / 07 \\
9 / 29 / 06\end{array}$ & $\begin{array}{c}100 \% \\
93-100 \% \\
100 \% \\
100 \%\end{array}$ \\
\hline
\end{tabular}




\section{Basic laboratory studies}

In basic laboratory studies, a long term project was to clone a key protein of the enzymatic machinery of the plant that responds to Outrider. Much effort was expended to isolate and sequence the Outrider receptor. Plans were to eventually clone and express the protein as an aid to improve treatment efficacy and to search for additional Johnsongrass control agents. Oneand two-dimensional gel electrophoresis systems were used to resolve active fractions into individual protein components for amino acid sequencing. The protein turned out to be resistant to fragmentation as well as to $\mathrm{N}$-terminal sequencing. Cells producing monoclonal antibodies to the protein would not grow and the producing cell lines could not be expanded. A potential plant homolog was cloned based on sequence similarity to a related human protein. The homolog was cloned and expressed in bacteria. The activity of the cloned protein was inhibited by Outrider with an $\mathrm{EC}_{50}$ of $100 \mathrm{~nm}$ (Figure 10) suggesting that the cloned protein was at least a member of the correct protein family. Further homolog searches did not reveal a plant homolog.

\section{7) CONCLUSIONS}

The following observations are now firm based on several seasons of regrowth evaluations:

1. For a broad-cast application optimum results ( 70 to $100 \%$ control the season following application) is achieved by a rate of $1 \mathrm{oz} / \mathrm{A}$ Outrider plus detergent $(0.012 \%)$ (Figs. 11 and 12; Table 8 ). Less is too little. More does not help. Addition of roundup or spraying before or after roundup does not change the outcome. There is no clear pattern with stage of growth although best results are usually achieved for growth or regrowth between 20 and 30 inches and prior to formation of seed heads. High volume (40 gpa) applications appear superior to low volume (10 gpa) applications.

2. The most cost effective method of application sufficient to achieve Johnsongrass eradication is a spot application (handgun or single truck-mounted nozzle) of $1 \mathrm{oz}$ Outrider/100 gal of water applied to the point of runoff (Figs. 11-14). Control is frequently $100 \%$ and normally $>90 \%$ depending, most likely, on efficiency of coverage. There is no clear pattern of dependency on stage of growth or regrowth but the treatment has the advantage of being able to eradicate Johnsongrass at all stages of growth following mowing including flowers in boot, flowering and mature seed heads right up until a few weeks before frost. Mowing as soon as 1 day after spraying does not affect outcome. Despite the manufacturer's claim that Outrider is rainproof, rain within about 1 hour of application or before the spray droplets have dried has resulted in reduced effectiveness in our experience.

3. Roundup does not eradicate Johnsongrass. Regrowth the year following treatment may be delayed or appear weakened but, by the end of the season, the stand density is approximately the same as that recorded the previous year at the time of spraying. 


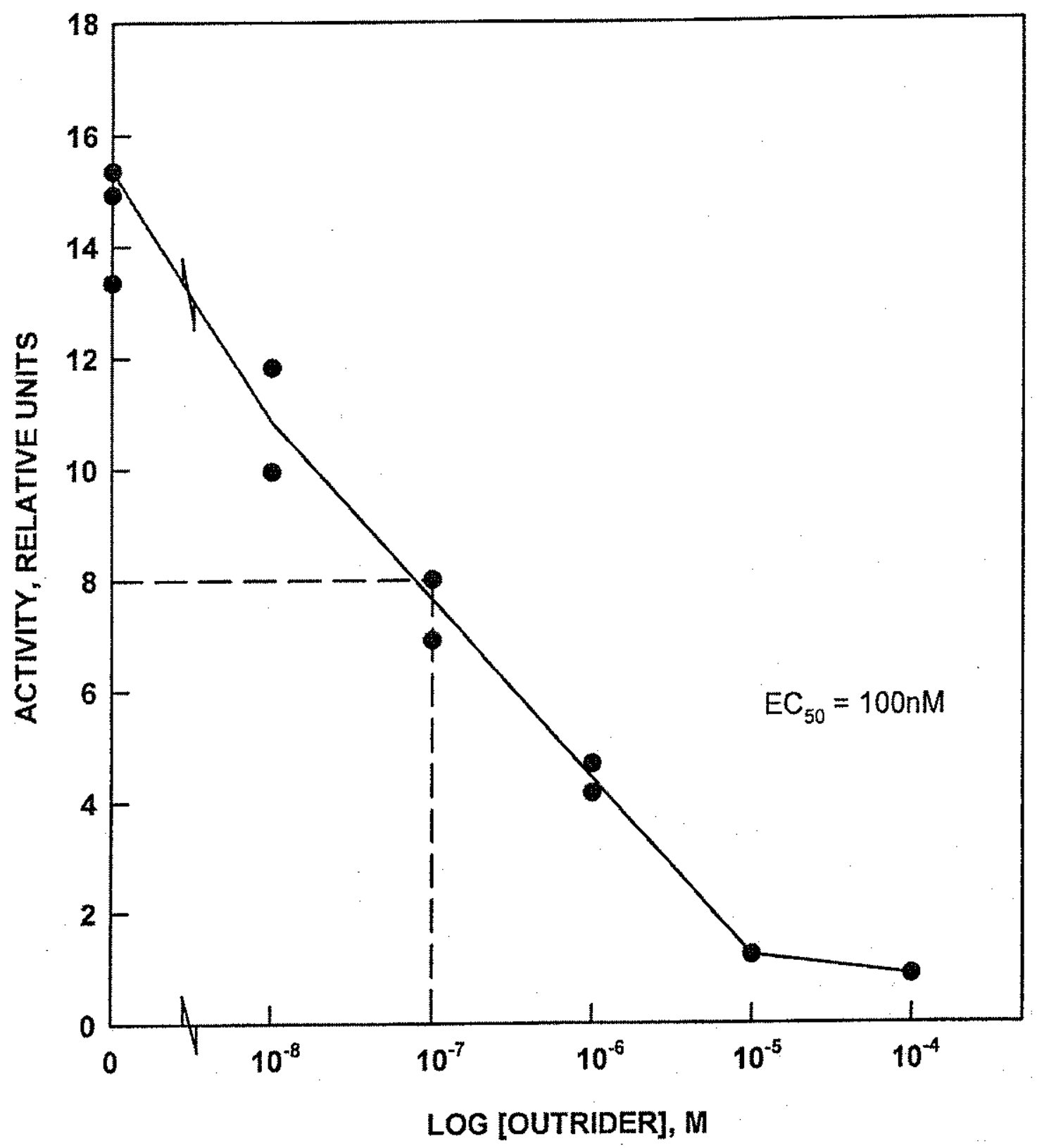

Figure 10. Inhibition of activity of the candidate Outrider receptor protein expressed in bacterial by different concentrations of Outrider. 


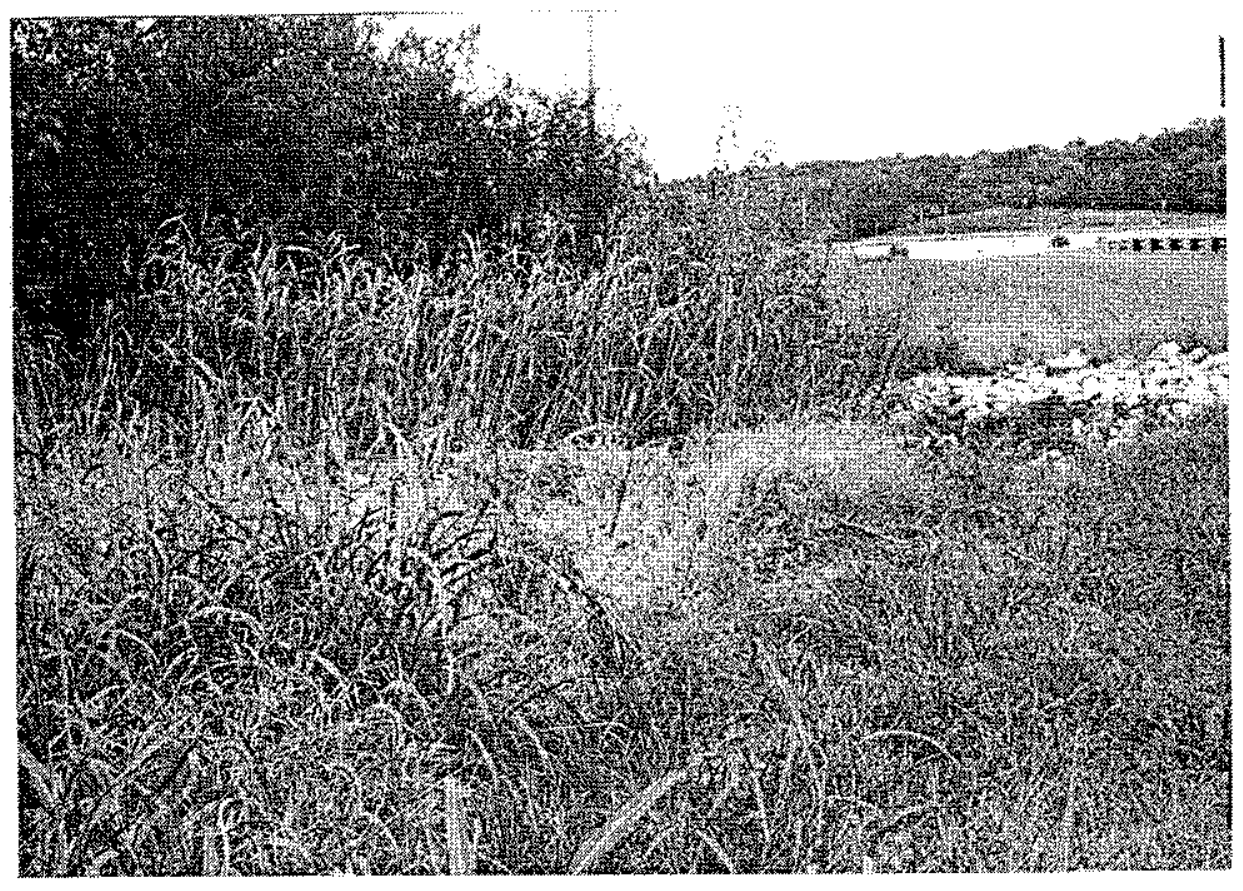

Figure 11. Area adjacent to US 41 north of Terre Haute containing both mowed and unmowed Johnsongrass photographed on September 10, 2007 at the time of spraying with 0.5 oz/100 gal Outrider plus detergent at $0.12 \%$ of the total spray mixture.

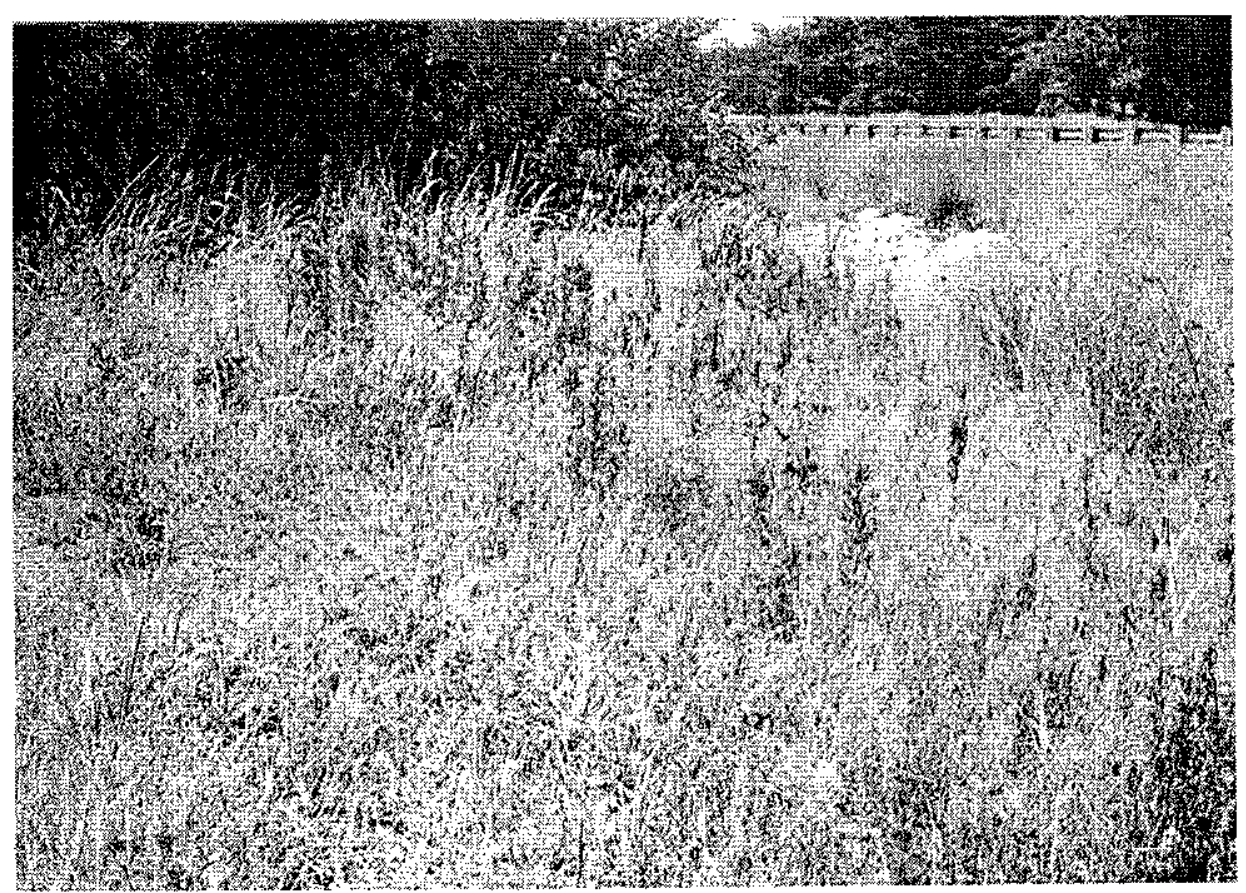

Figure 12. Same area as Figure 11 photographed on August 17, 2008 one year after spraying. Control of both mowed and unmowed Johnsongrass was $90 \%$. 
TABLE 9

EFFECT OF DETERGENT

\begin{tabular}{l|c|c|}
\hline \multicolumn{2}{c}{$\%$ Control } \\
Rate of Outrider & No Detergent & Plus Detergent* \\
\hline None & $10 \%$ & - \\
\hline $0.25 \mathrm{oz} / \mathrm{A}$ & $15 \%$ & $0 \%$ \\
\hline $0.5 \mathrm{oz} / \mathrm{A}$ & $-12 \%$ & $25 \%$ \\
\hline $0.75 \mathrm{oz} / \mathrm{A}$ & $53 \%$ & $80 \%$ \\
\hline $1 \mathrm{oz} / \mathrm{A}$ & $100 \%$ & $61 \%$ \\
\hline
\end{tabular}

*Detergent was $0.1 \%$ of the total spray mixture at $40 \mathrm{gpa}$.

In subplots, the Johnsongrass had been either mowed (18" regrowth) or unmowed (56" with seed heads). 


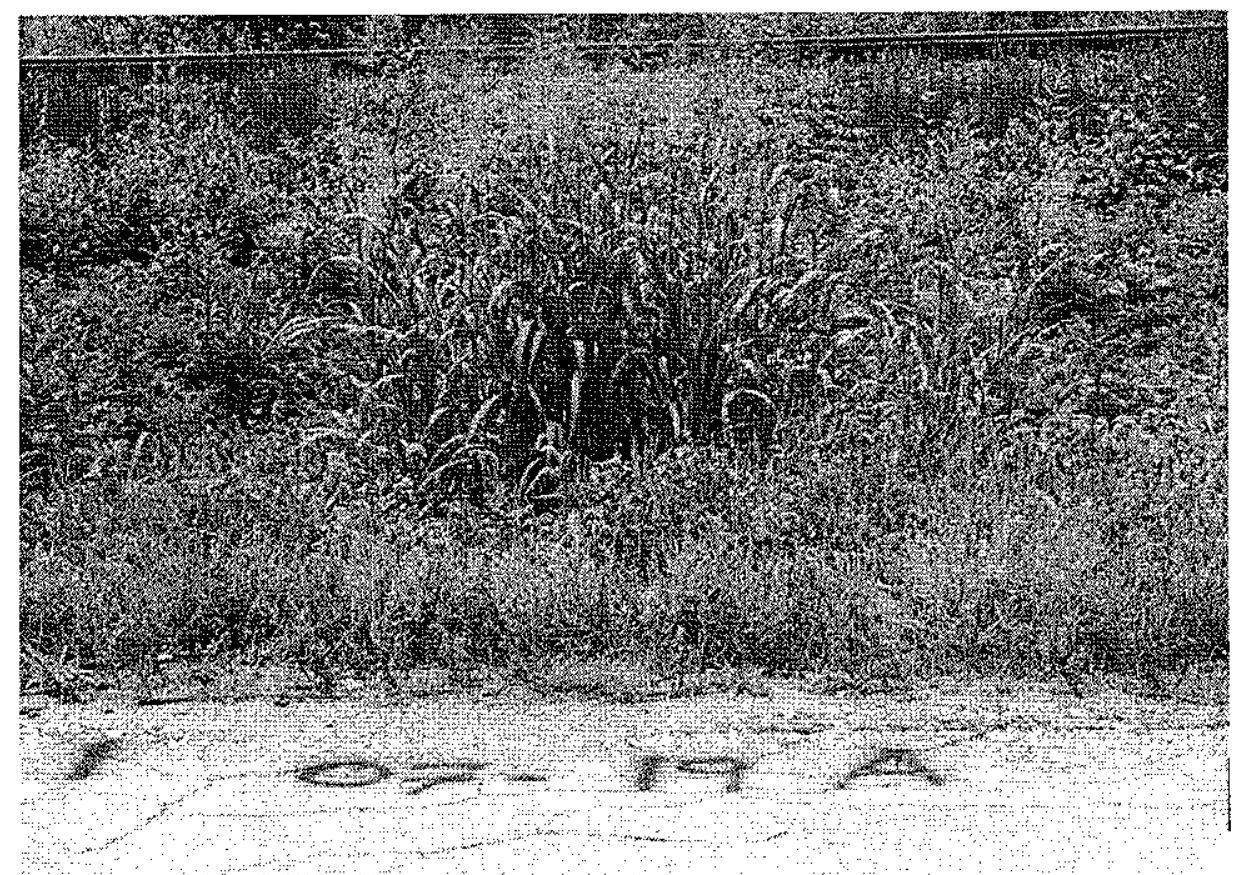

Figure 13. 2007 implementation trial in Uniform Test Area adjacent to US $63 \mathrm{~S}$ at intersection with US $36 \mathrm{~W}$. The Johnsongrass was about 5 feet tall and in late flower. The Johnsongrass was sprayed on September 10, 2007 with 0.5 oz Outrider per 100 gal + detergent at $0.12 \%$ of the total spray mixture.

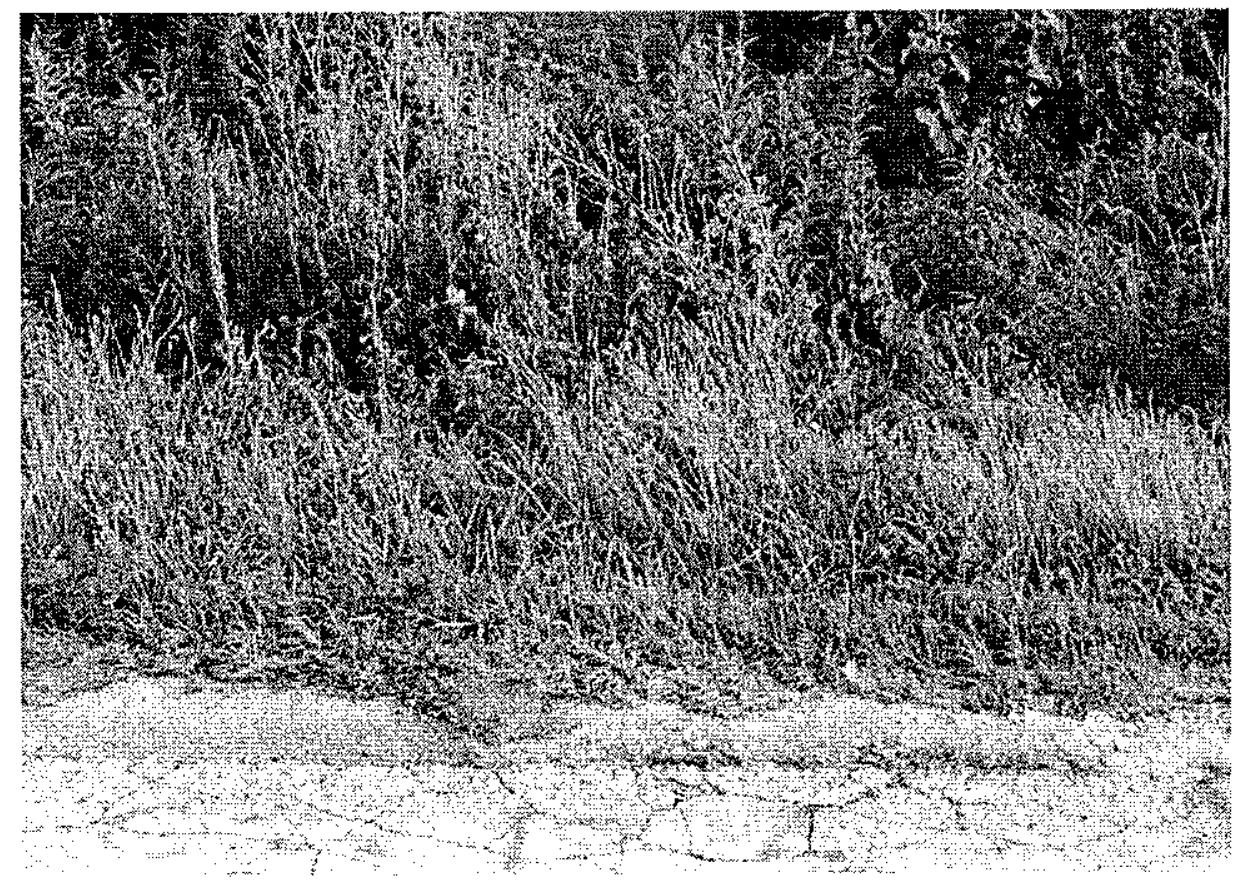

Figure 14. The same area as shown in Figure 13 photographed on July 19, 2008 one year after spraying. The Johnsongrass was completely controlled. 


\section{8) REFERENCES}

1. Morré, D. J. 2005. New combination treatments for control of Johnsongrass along roadsides. Federal Highway Administration, Joint Highway Research Project, Purdue University, West Lafayette, IN, FHWA/IN?HTRP-2004/9, 54 pp.

2. McWhorter, C. G. 1972. History, biology, and control of Johnsongrass, Res. Weed Sci. 4: 85-121.

3. McWhorter, C. G. 1972. Factors affecting Johnsongrass rhizome production and germination, Weed Sci. 20: 41-45.

4. Satorre, E. H., C. M. Ghersa and A. M. Pataro. 1985. Prediction of Sorghum halepense (L.) Pers. Rhizome sprout emergence in relation to air temperature, Weed Res. 25: 103109.

5. Ghersa, C. M., E.H. Satorre and M. L. Van Esso. 1985. Seasonal patterns of Johnsongrass seed production in different agricultural systems, Israel J. Bot. 34: 24-31.

6. Leguizamon, E. S. 1986. Seed survival and patterns of seedling emergence in Sorghum halepense (L.) Pers., Weed Res. 20: 397-404.

7. Mitchell, J. K., M. Mjalamimba-Bertsch, N. R. Bradford and J. A. Birdsong. 2003. Development of a submerged-liquid sporulation medium for the Johnsongrass bioherbicide Gloeocercospora sorghi, J. Ind. Michrobiol. Biotechnol. 30: 599-605.

8. Barrentine, W. L. and C. G. McWhorter. 1988. Johnsongrass (Sorghum halepense) control with herbicides in oil diluents, Weed Science 36: 102-100.

9. Brooks, R. L., M. G. Merkle and J. M. Chandler. 1985. Efficacy of glyphosate/adjuvant combinations for Johnsongrass control, Proc. South. Weed Sci. Scoc. 38: 46.

\section{9) FINAL RECOMMENDATIONS}

The final recommendation for flexible single pass eradication of Johnsongrass along Indiana roadsides is for a spot treatment (handgun or single truck-mounted nozzle) of $0.5 \mathrm{oz} / 100$ gal. Outrider $+0.12 \%$ detergent ( 1 pint $/ 100$ gal) applied to the point of runoff at any stage that the Johnsongrass is visible above the surrounding vegetation (20 to 30 inches of growth or regrowth after mowing up to and including late seed head formation). The possibility of rain within one hour of application is to be avoided. To be safe, mowing should be delayed at least until the day following spraying.

\section{0) IMPLEMENTATION SUGGESTIONS}

Awaiting recommendations of SAC. 